Tesis para obtener el grado de

Magíster en Comunicación y Derechos Humanos

\author{
CASA AJENA
}

Retrato de una familia colombiana exiliada

en Latinoamérica

Miriam Fernanda González Velásquez

Periodista

Lic. María Eugenia Ludueña

Directora

La Plata

Diciembre de 2017 


\section{Casa Ajena}

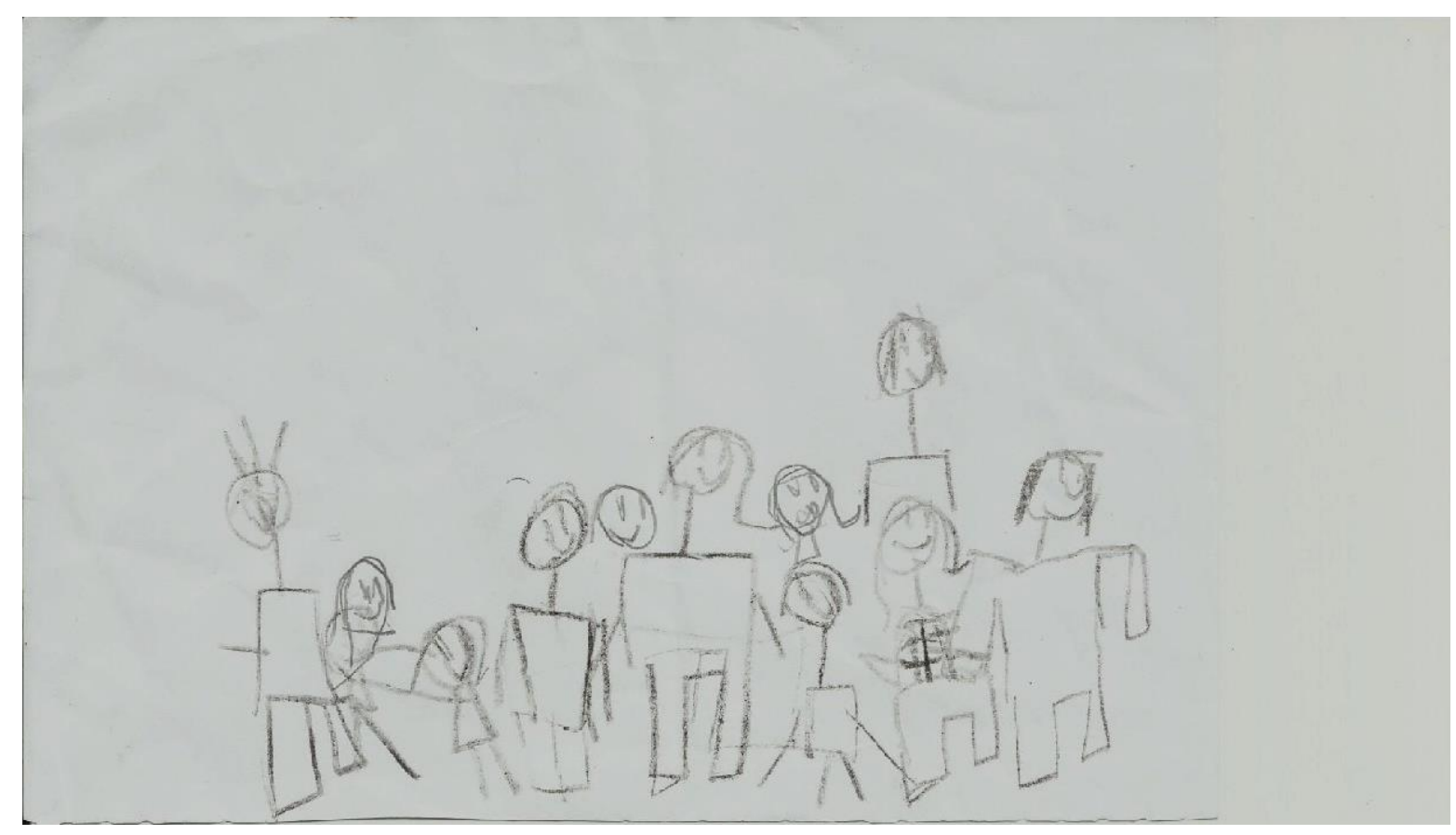

Los Mejías Salazar. Dibujo realizado por la hija menor de la familia. 
A todas las familias colombianas cuyas memorias fueron desterradas por la guerra. 


\section{Tabla de contenido}

CARTA AL LECTOR

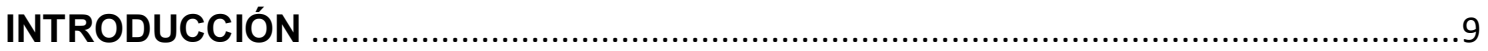

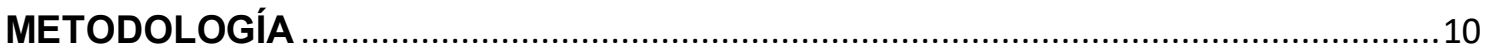

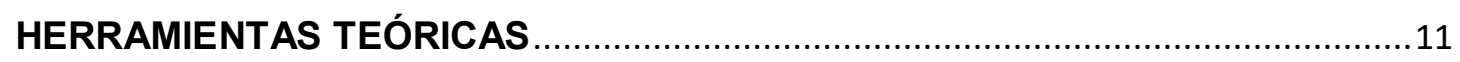

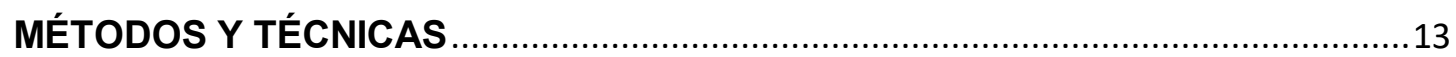

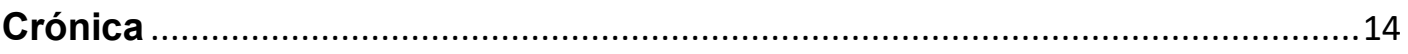

Ensayo

Objetos de memoria

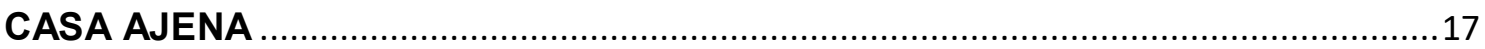

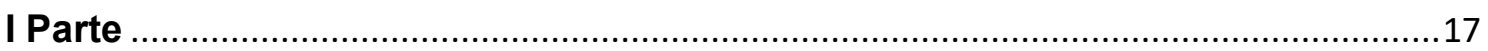

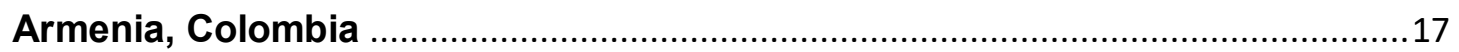

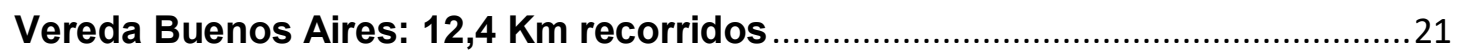

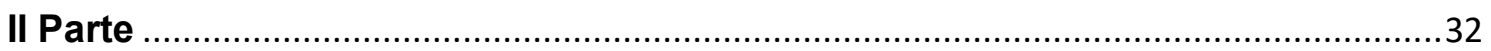

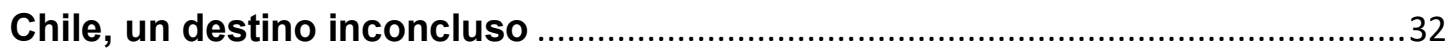

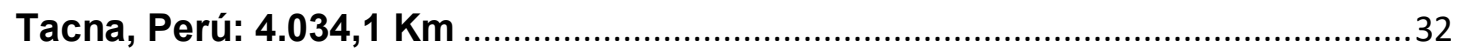

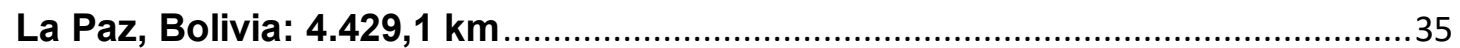

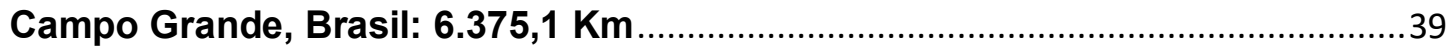

Buenos Aires, Argentina: 8.443,4 km, un amparo sin status.............................43

EPÍLOGO

El fin de la guerra, el fin del exilio para los Mejía Salazar ....................................45

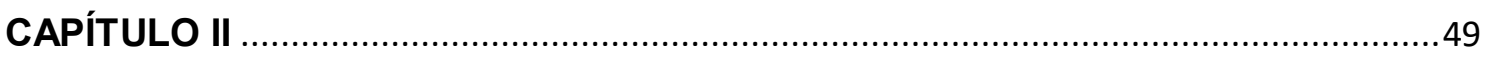

EL EXILIO COLOMBIANO, LA DISPUTA AUSENTE ............................................49

ANTECEDENTES DE EXILIO EN LATINOAMÉRICA ............................................5

COLOMBIA, NUEVO EXILIO EN SURAMÉRICA .................................................... 
EL DESCONOCIMIENTO DEL EXILIO EN COLOMBIA

1. LA NORMATIVA DE “LAS VÍCTIMAS EN EL EXTERIOR” ................................57

1.1. ORGANIZACIONES DE "VÍCTIMAS EN EL EXTERIOR" .60

2. DESPLAZAMIENTO FORZADO INTERNO COLOMBIANO

2.1 SURAMÉRICA, ÚLTIMO GRAN RECEPTOR DE POBLACIÓN EXILIADA COLOMBIANA

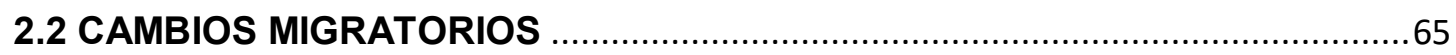

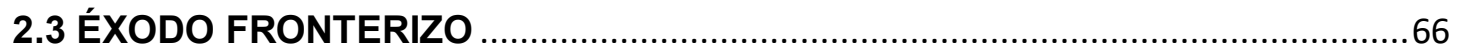

2.4. PERFIL DEL REFUGIADO EN LA REGIÓN: COLOMBIANO CAMPESINO, INDÍGENA, AFROCOLOMBIANO

3. PERFILES DE EXILIADOS COLOMBIANOS ENTRE LO AUTÉNTICO Y LO

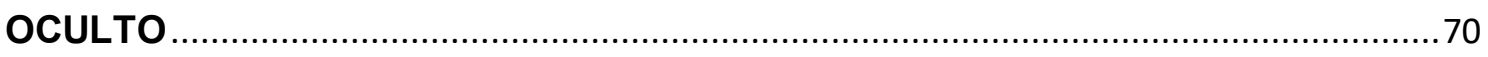

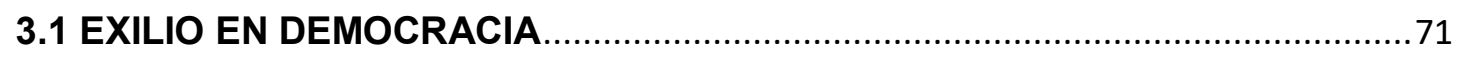

3.2. EXILIADOSIAS: SOBREVIVIENTES DEL EXTERMINIO ................................74

CAPÍTULO III

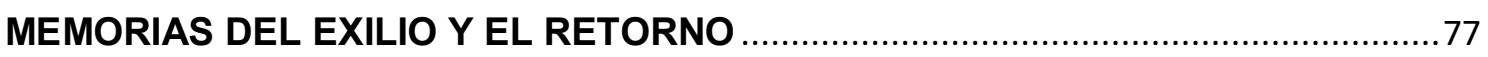

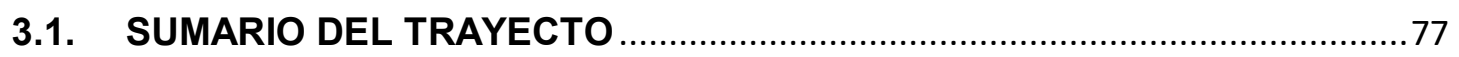

3.2. CASA AJENA (EXILIO, 2015- RETORNO, 2016) …...................................78

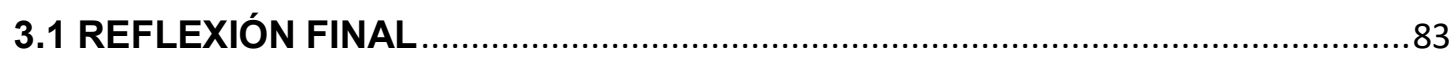

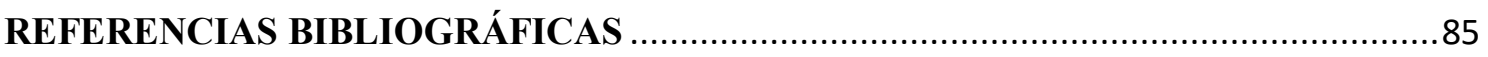




\section{CARTA AL LECTOR}

Puedo decir que no me interesé por la migración forzada como objeto de estudio, sino que ella me precede; se sitúo sobre mi casa o, mejor dicho, en las diferentes casas que tuve con mi familia. Pero en este espacio no detallaré cómo la guerra colombiana bordeó las puertas de mi hogar, donde cada tanto había que huir de algo, de alguien o algunas veces, de las sombras de pensamientos persistentes de persecución. No lo haré, entre algunas razones, porque me siento incluida en el relato colectivo que, en general, aquí se presentará.

La migración forzada creció cerca de mí, cuando ni siquiera sabía escribir. Luego, siendo estudiante de Periodismo en la Universidad de Antioquia en Medellín, Colombia, -en una región que no era la natal- escuché otros relatos de migración forzada y decidí enfocarme en ellos para conocer el país. Ni en mi casa- siempre fui la niña menor- ni en la escuela, ni en los grandes medios de comunicación me informaron exactamente de cómo era el conflicto armado interno, que parecía un ente externo, AJENO.

Pienso que el silencio de la guerra y el miedo al otro, aísla tanto que se llega a creer que "Ios enemigos" están solo en contra de uno mismo, no de una sociedad. No se dimensiona la guerra porque los silencios-el que proviene de un convenio y el que está amordazado-, a veces hacen pensar que es diminuta, insignificante.

El Periodismo y la Maestría me sirvieron como herramientas para conocer y compartir historias de migración forzada. En mi tesis de grado, investigué las vidas de tres mujeres antioqueñas, víctimas de desplazamientos internos. Decidí continuar en esa misma línea de estudio en el postgrado. Esta investigación aborda el tema de la migración forzada externa desde un microrrelato de resistencia familiar, enmarcado en un fenómeno más extenso: el exilio colombiano por causa del conflicto armado.

Escuché las historias desde la voz de las personas que la resistieron y algo de ellas, intenté escribir. Movida, quizás por la sensación infantil que de pronto si alguien lee una historia de resistencia de los sobrevivientes del conflicto 
colombiano, posiblemente no sienta que vivió la guerra, cualquier guerra, solo. Es decir que, aunque pareciera, la guerra no fue solo contra él, ella o su familia. Y por supuesto, motivada por la convicción de que la memoria crece y traspasa.

En términos globales, la migración nos sigue afectando como humanidad. Termino de editar esta tesis en el archipiélago de Malta, en la mitad del Mediterráneo. Desde hace seis meses soy voluntaria de Cruz Roja en el área de Refugiados. Con el transcurso de los días, me topo con el fenómeno de la migración forzada en otro continente. Hay distancias enormes entre los refugiados colombianos y los refugiados africanos o los de Medio Oriente. Pero existe una constante: los derechos se siguen vulnerando.

Esta investigación no será una tesis comparativa entre "la crisis migratoria actual" con la migración forzada colombiana, aunque en esta carta sí me permito hacer algunos apuntes generales, que considero comunes. Dicha migración no es un problema solo de cifras, de dinero o de acuerdos, es un problema humano. "La crisis de refugiados" es también la crisis de un sistema de derechos aplazados. Los migrantes forzados sobreviven a un ataque sistemático a la vida. Huyen como seres anónimos y la mayoría de las veces subsisten, desaparecen o mueren ignorados.

Una gran implicación de estos sucesos es el olvido histórico de las circunstancias que rodean a los migrantes forzados. No solo son borrados de la memoria social del lugar de destierro, sino que, en gran parte de los casos, son anónimos en sus lugares de arribo. Anónimos, aunque señalados por estigmas, prejuicios, estereotipos que a veces se convierten en paradigmas imaginarios, perfiles irreales.

Las desigualdades que sufrieron pueden padecerlas otros cientos de migrantes en otros lugares del mundo. Y, sin embargo, siguen siendo personas anónimas de las que solo de vez en cuando conocemos una ínfima parte de su historia a través de plataformas comunicativas de las organizaciones humanitarias, o de una foto con cuerpos flotantes que se vuelve "viral" en las redes sociales. En gran medida, su resistencia no está siendo ni contada por su propia voz, ni mucho menos escuchada. Es común que las campañas de entidades no gubernamentales soliciten ayudas monetarias, no es una mala idea, aunque sí 
una idea insuficiente porque la ayuda no restablece sus derechos. La caridad no es suficiente, a cualquier migrante forzado del mundo sólo lo dignificará los derechos.

En este trabajo, aparecerá un fragmento de la historia de la familia colombiana Mejía Salazar. Narrar su historia o la de cualquier migrante forzado es un pequeño paso para evidenciar las violencias que han sufrido y las resistencias con que las que se han enfrentado. La comunicación y los derechos podrían ser sus salvavidas, pues ayudaría a dar a conocer este fenómeno y, sumada a otras historias, en el futuro podría ser un pequeño aporte al diseño e implementación de políticas acordes con la realidad. 
Madre, lo siento porque el barco se hundió

$Y$ no pude llegar a mi destino

No podré enviar dinero

para devolver la deuda

Que contrajimos para pagar el viaje

Madre, no llores sino encuentran mi cuerpo

De todos modos, ¿Qué harías con él?

La búsqueda, el transporte, el entierro y el duelo

Todo sería caro

Madre, siento que la guerra se intensificara

$\mathrm{Y}$ que yo tuviera que escapar como otras personas,

Incluso aunque mis sueños no fueran tan ambiciosos.

Mis sueños eran tan grandes como tu caja de medicamentos y

Tan caros como arreglarte los dientes

Lo siento, mi casa hermosa, porque ya no colgaré mi abrigo detrás de tu puerta

Lo siento buzos y equipos de búsqueda y rescate, porque no sé el nombre del mar donde me ahogué

No te preocupes, Oficina de Asilo y Refugio no seré una carga

Gracias, inmenso mar azul, por darnos la bienvenida sin pedirnos visado o pasaporte.

Gracias, peces, por compartir mi carne sin preguntarme de dónde vengo, cuál es mi religión o mi afiliación política

Gracias, canales de noticia, por transmitir esta última hora sobre nuestras muertes durante cinco minutos cada hora, durante dos días enteros

Gracias por ponerte triste cuando escuches la noticia

Siento haberme ahogado ${ }^{1}$.

\footnotetext{
${ }^{1}$ Estas palabras aparecieron online y proceden supuestamente de una carta encontrada en el cadáver de un refugiado sirio ahogado. El País. 27 de julio de 2017.

https://www.youtube.com/watch?v=8Se2PM-QmnM
} 


\section{INTRODUCCIÓN}

Esta tesis es un recodo de lo que ha dejado la guerra en Colombia y es también un testimonio de lo poco que conocemos la migración forzada externa a causa del conflicto armado por más de 50 años.

La victoria de los victimarios no fue tanto intimidar y expulsar del país, sino también que una sociedad desconociera el relato de la migración. El miedo, el silencio y el estigma robó tantos derechos como lo hicieron las armas.

Esta es una investigación abrazada a una narración con la experiencia, los recuerdos y las marcas recientes del conflicto, el exilio y el retorno de un grupo familiar colombiano refugiado en Latinoamérica: la familia Mejía Salazar, que representa con su narración la lucha de otros grupos similares a los que aún hoy no se les ha permitido recordar en público.

A pesar de que la vida de los migrantes forzados no puede comprenderse sin las atrocidades que vivieron a causa de la guerra, ni sin las resistencias que los mantuvieron con vida, Colombia sigue sin reconocerlos. Y sin elevar lo suficiente su relato como tributo a la memoria histórica.

Aquí se cuenta el testimonio de una sobrevivencia a lo largo del tiempo, la tensión constante entre violencia, derechos y lazos de una familia migrante forzada, integrada por once miembros. En sus trayectos forzados por su propio país (2002-2006) y por seis países suramericanos (2006-2015) no aprendieron de la muerte sino de la vida. La guerra pensó en enterrarlos en el olvido, como respuesta ellos engendraron estrategias, sueños campesinos, hijos e hijas. Fueron tan perseverantes que luego de diez años de exilio, retornaron a su país de origen.

Para desdicha de los actores de la guerra, el destierro colombiano regó algunas semillas para la memoria, que probablemente, crecerán en el proceso de construcción de paz y de democracia participativa. 


\section{METODOLOGÍA}

La primera parte de esta tesis narra en una crónica el relato de vida y resistencia de una familia colombiana exiliada en Suramérica durante diez años. En este trabajo hablan las once voces que integran la familia Mejía Salazar. Reúne también los ecos de otras memorias del exilio, que han sido lanzadas al destierro y al olvido.

En el capítulo dos de esta tesis, se describe el estado actual de la normativa de los exiliados, actualmente no reconocidos por el Estado colombiano. Se sitúa la ausencia social, jurídica e histórica que existe en Colombia acerca del fenómeno del exilio en, al menos, 50 años de conflicto armado interno.

El último capítulo cuenta sobre las muestras estéticas y comunicativas basadas en la memoria de la familia Mejía Salazar. A través de estas muestras se dieron a conocer sus objetos personales, que sobrevivieron al destierro y algunos incluso, al retorno. La primera se expuso en la ciudad de La Plata, Argentina (2015) en la sede de postgrado de la Facultad de Periodismo y Comunicación Social y la segunda tuvo lugar en Bogotá D.C, Colombia (2016) en el marco de talleres de memorias del Centro Nacional de Memoria Histórica, $\mathrm{CNMH}$.

Casi al final de cumplir los objetivos planeados en esta investigación, la familia retornó a Colombia. Ese episodio de su vida quedó registrado en una crónica publicada en el medio Pacifista. A manera de epílogo, el artículo también forma parte de la tesis. Es de ese modo como este trabajo tiene un final abierto, actualmente Colombia cuenta con una familia más para construir memoria, esperanza, paz y democracia. Las circunstancias históricas y la resistencia familiar irán marcando los trayectos sociales de cada miembro. 


\section{HERRAMIENTAS TEÓRICAS}

Esta investigación tuvo como objetivo principal narrar desde las voces del grupo familiar las estrategias de supervivencia durante la migración forzada. A partir de lo encontrado en su historia, se analizó el tratamiento social y político de la categoría exilio como migración oculta del conflicto armado interno colombiano. También se mostraron las vivencias del exilio con los objetos de memoria de la familia en dos instalaciones artísticas realizadas en La Plata, Argentina (2015) y Bogotá, Colombia (2016)

Para esto, Carlo Ginzburg, quien trabajó el paradigma indicial, fue una referencia importante. Mediante este enfoque se analizaron las huellas históricas de la familia Mejía Salazar en su expulsión y desplazamiento, y se evidenció un fenómeno más amplio: las resistencias de los migrantes forzados colombianos en un determinado contexto social histórico.

El paradigma indicial como modelo epistemológico nace a finales del S.XIX y para Ginzburg tiene su origen en la fábula oriental de tres hermanos que a partir de una interpretación de indicios logran identificar un animal que nunca han visto" $^{2}$. El autor dice que "si la realidad es impenetrable existen zonas privilegiadas-pruebas, indicios- que permiten descifrarlas".

Con lo cual es posible dimensionar una totalidad, es decir que algunos rasgos individuales o en este caso familiares, pueden llevar a descubrir fenómenos más generales, por ejemplo "la visión del mundo de una clase social o de una sociedad entera". Entre las disciplinas pioneras en este aspecto está el psicoanálisis en la que "ciertos detalles desdeñables podían revelar fenómenos profundos de notable amplitud"3.

Como lo muestra el autor, el poder estatal también se ha valido de indicios individuales, como las huellas dactilares, para convertirlas en un sistema de

\footnotetext{
${ }^{2}$ Ginzburg, Carlo. (2008). Mitos, emblemas e indicios: Morfología e historia. Editorial Gedisa. Barcelona, España P. 210

${ }^{3}$ Ibíd. P. 219
} 
identificación más exacto. Así como ha sido un aporte para el control social, de igual forma lo puede ser para investigar aspectos invisibilizados por el mismo control social.

Es lo que ocurre en el análisis de El queso y los gusanos que evidencia a partir de la historia de Menocchio, Ginzburg identifica las creencias populares y la visión del mundo y de la época de los campesinos del S. XVI. No solo tiene en cuenta la documentación de la Inquisición, donde aparecen los testimonios del molinero, sino que señala cómo los acontecimientos históricos -la imprenta y La Reforma- ayudan a comprender las características de los campesinos y los vínculos con la clase dominante: "En algunos estudios biográficos se ha demostrado que en un individuo mediocre, carente en sí de relieve y por ello representativo, pueden estructurarse, como en un microcosmos, las características de todo un estrato social en un determinado período histórico" 4 .

Similar perspectiva aporta Oscar Lewis en una autobiografía sobre una familia mexicana: Los hijos de Sánchez, que reúne una serie de rasgos de "la cultura de la pobreza", como lo denomina el autor: "un patrón de vida que pasa de generación en generación" ${ }^{5}$. Y de ahí sale una historia de la vida familiar en la que cada individuo participa con su ideología y la manera de actuar frente a determinadas situaciones. Esta investigación es una ampliación de una de las familias mexicanas entrevistadas para su proyecto 'Antropología de la Pobreza'. En un "intento por proporcionar el retrato viviente de un segmento de esos millones de seres, por el procedimiento del muestreo profundo" 6 y a la vez, instaurar un realismo social en el que los protagonistas relatan sus experiencias "en una forma sin inhibiciones, espontánea y natural" como lo dice Oliver La Farge en el prólogo ${ }^{7}$.

Por ese mismo camino se dirigió esta investigación, que esté contada "en primer lugar por los protagonistas y sólo después por los especialistas (...) amonedando en palabras los dramas y maravillas del pasado y el presente" ${ }^{\text {. }}$

\footnotetext{
${ }^{4}$ Ginzburg, Carlo (2008). El queso y los gusanos. Ediciones Península. Barcelona. P. 21

${ }^{5}$ Lewis, Oscar. (1966). Los hijos de Sánchez. Editorial Joaquín Mortís. México. P. 14

${ }^{6}$ Lewis, Oscar. (1961). Antropología de la Pobreza. Fondo de Cultura Económica. México. P.12

${ }^{7}$ Ibíd. P. 22

${ }^{8}$ Ospina, William. (2001). Colombia en el Planeta. Gobernación De Antioquia Secretaría de Educación y Cultura Dirección de Cultura. Medellín.
} 


\section{MÉTODOS Y TÉCNICAS}

Este proyecto hace parte de una "historia oral temática", como lo denomina Aceves Lozano (1998) $)^{9}$ ya que pretende abarcar un tema de investigación a través de relatos de vida de una familia. Es el relato de varios integrantes, pero además por medio de ellos se pueden conocer otras historias de la migración forzada. En definitiva, su historia es un indicio de un fenómeno más amplio.

Como advierte Cipriani (2013), el dato biográfico nunca tiene un contenido sólo personal, sino que contiene puntos de conexión con la comunidad local y con la sociedad en general. Con lo cual, se tiende a "reconstruir la realidad social"10, que para esta investigación estaría enmarcado por los contextos políticos, históricos y sociales donde ocurren los motivos del desplazamiento en Colombia y la migración latinoamericana. Serían "los confines de la realidad" a los que alude Cipriani. En palabras de Mertnes (2005), pertenecería a un "estudio narrativo de tópico": enfocado a una temática, suceso o fenómeno. Entre las acciones para llevar a cabo un estudio narrativo, enumera: planteamiento orientado a entender y representar experiencias por medio de historias de vida de individuos o grupos ${ }^{11}$.

Para este proyecto, se tomarán los diseños propuestos por este autor. Teniendo siempre en cuenta que "no se trata de hacer psicología intimista sino de excavar en el microcosmos para entrever el macrocosmos"12.

\footnotetext{
${ }^{9}$ Aceves Lozano, Jorge E. (1998). La historia oral y de vida: del recurso técnico a la experiencia de investigación. En Galindo Cáceres, Luis Jesús, Técnicas de investigación en sociedad, cultura y comunicación, Ed. Addision Wesley Longman. P.P 3-4

${ }^{10}$ Cipriani, Roberto. (2013). Sociología Cualitativa. Las Historias de vida como metodología científica. Editorial Biblos. Buenos Aires. P.24-25

${ }^{11}$ Hernández Sampieri, Roberto; Fernández Colledo, Carlos; Pilar Baptista, Lucio. (2006). Metodología de la Investigación. Cap. 15 Diseños del proceso de investigación cualitativa. Quinta Edición, Mc Grall Hill. P. 506

${ }^{12}$ Ibíd. P.28
} 


\section{Crónica}

Cuando la familia migró de Colombia, estaba conformada por la pareja y siete hijos. Los últimos dos, para el momento del desplazamiento eran niños de 6 y 4 años de edad, que hoy tienen pocos recuerdos de la trayectoria ${ }^{13}$. Inicialmente, se tomó como fuentes principales tres integrantes de la familia: la pareja y su hija mayor. En un primer momento, las entrevistas estuvieron dirigidas a la hija.

Luego, con el avance del proyecto se accedió a entrevistas con los padres de familia. En esa etapa se tuvo como lugar de las entrevistas su hogar en Argentina. En su casa se pudieron observar las dinámicas familiares cotidianas. En la mayoría de los casos se contó con la participación de los otros integrantes de la familia. En cuanto a los testimonios familiares, como experiencia colectiva, "no es una categoría que se limite a producir enunciados de verdad o falsedad, sino más bien, habría que considerarlos como una percepción particular de las cosas, una versión' personal de los hechos, acontecimientos, acciones personales, etcétera, que, tamizados por los flujos de la memoria y la experiencia reciente, proporcionan texturas nuevas a los testimonios" ${ }^{14}$.

La inmersión en el hogar también permitió otras maneras de testimonio, como recuerdos infantiles alusivos más a los sentidos. Por ejemplo, el recuerdo de la temperatura en un determinado lugar, los juegos que adaptaron en los refugios para poder cumplir con las reglas de las casas de acogida, el tipo de comida o las palabras nuevas que aprendían en cada zona. Esto dio apertura a un paso muy importante, que no estaba planeado en el proyecto, y fue la introducción de la memoria a través de dibujos. En ellos el recuerdo quedaba mejor plasmado que con la palabra. Así, esta investigación se enriqueció con otras perspectivas del hecho migratorio como la etaria y la de género, y plasmó diversas formas de rememorar. Las imágenes fueron un material fundamental en las exposiciones con los objetos de la familia y algunas ilustran estas páginas.

\footnotetext{
${ }^{13}$ En el presente la familia está conformada por la pareja y nueve hijos, de los cuales dos nacieron en el exilio.

${ }^{14}$ Aceves Lozano, Jorge E. (1998). La historia oral y de vida: del recurso técnico a la experiencia de investigación. En Galindo Cáceres, Luis Jesús, Técnicas de investigación en sociedad, cultura y comunicación, Ed. Addision Wesley Longman. P.12
} 
La historia de los Mejías Salazar es también una historia que busca una visión del pasado reciente del país y de parte del continente, algo que está presente, vivo y que se pretende reconstruir para no olvidar: "Reconstruir el pasado desde la óptica del recuerdo y la memoria, es reconstruir la historia, es reinterpretar y aportar una nueva versión de lo acontecido y, por supuesto, no es el relato puntual de lo que históricamente aconteció. Para ello, existen otras fuentes y técnicas más apropiadas. En este trabajo, lo que interesó, por lo tanto, fue conocer la visión que de los cambios tienen nuestros informantes, la experiencia decantada por los años de sus vivencias, la concepción queda distancia y la propia biografía marcan en sus recuerdos y liberan por momentos su memoria" 15 .

Por otro lado, la crónica hace referencias a algunos hechos históricos relevantes y puntuales para comprender las decisiones a las que se vio obligada la familia tanto en Colombia como en los países por los que transitan y se refugian. Además, en la crónica se recurrió a documentos, la prensa y a "las fuentes monumentales", que serían los objetos de memoria (de las que se hablará más adelante). Esto se hizo con el propósito de evitar que el relato de vida sea visto como un hecho aislado, excepcional y alejado de las circunstancias pasadas y presentes de Colombia.

\section{Ensayo}

Como lo manifiesta Aceves, "las historias de vida también se usan al revés, tal como si fueran experimentos o pruebas de campo y exploración preliminares, que nos ayudan a realizar acercamientos al sujeto de estudio, o bien a detectar nuevas líneas de investigación para probar hipótesis específicas de la investigación", en esta investigación se describieron y pusieron en tensión planteamientos contemporáneos que incluyen la democracia, el exilio y el conflicto armado, todas líneas que surgieron a partir de la historia de vida la familia. Por eso el análisis y lo subrayado en el ensayo no está solamente basado en las interpretaciones acerca de la migración forzada, los perfiles y la normativa de la autora y en los estudios de los expertos, sino que emerge y se debe en

\footnotetext{
${ }^{15}$ Aceves Lozano, Jorge E. (1998). La historia oral y de vida: del recurso técnico a la experiencia de investigación. En Galindo Cáceres, Luis Jesús, Técnicas de investigación en sociedad, cultura y comunicación, Ed. Addision Wesley Longman. P.12
} 
gran medida a los protagonistas de esta historia, como representación de un macrocosmos.

\section{Objetos de memoria}

Gracias a la inmersión en su cotidianidad y a la participación que despertaron las entrevistas en profundidad a los miembros menores de edad, la historia fue narrada de diferentes maneras, ángulos y con distintos materiales. Una de esas narraciones estuvo a cargo de los objetos personales que fueron apareciendo para, si se quiere decir de algún modo, "testificar" lo que contaban sus dueños. También tuvieron valor metodológico, al ayudar a rememorar hechos que se creían olvidados.

Todas ellas fueron las fuentes monumentales en esta investigación: "incluyen no sólo las construcciones humanas, sino todo tipo de objetos viables de ser utilizados por ejemplo en una exposición museográfica Instrumentos de trabajo, gráfica, fotografías, muebles, vestidos, colecciones de objetos curiosos, monedas, timbres, productos de multimedia" 16 .

Los objetos fueron seleccionados y luego, expuestos en dos instalaciones artísticas para narrar la historia de la familia. La primera en el 2015, cuando la familia era todavía exiliada y la nombraba Mejía Salazar, se realizó en los pasillos de la Facultad de Periodismo y Comunicación Social de la UNLP. Otra en el 2016, en Colombia y ya con el retorno de la mayoría de sus miembros. En la apertura del evento fueron llamados con sus apellidos reales: Vargas Garzón. Las muestras se convirtieron en un ejercicio colectivo de memoria, denuncia y reparación a través del arte y la comunicación. También en términos académicos, las muestras permitieron una presentación abierta a un público heterogéneo sobre las investigaciones recientes de la Maestría en Comunicación y Derechos humanos en conexión con Suramérica.

\footnotetext{
${ }^{16}$ Aceves Lozano, Jorge E. (1998). La historia oral y de vida: del recurso técnico a la experiencia de investigación. En Galindo Cáceres, Luis Jesús, Técnicas de investigación en sociedad, cultura y comunicación, Ed. Addision Wesley Longman. P.13
} 


\section{CASA AJENA \\ Ocho mil kilómetros de huidas}

Las fuerzas de la guerra empujaron a la familia Mejía Salazar ${ }^{17}$ a dejar Colombia. A diez años de huir de su patria y después de peregrinar por Latinoamérica en busca de refugio, su retorno es una apuesta por la paz.

\section{Parte}

Armenia, Colombia

El 25 de enero de 1999 Mercedes Salazar y Diego Mejía se despertaron con el malestar del trasnocho de dos días de fiestas populares. Debían prepararse para la cita odontológica, aun cuando sabían que se había hecho tarde. A la 1:18 p.m. Diego se terminó de duchar, se puso la salida de baño, miró hacia la ventana que daba a la calle y sin girar la cabeza dijo:

-Mercedes, se está moviendo la tierra.

Ella le preguntó: ¿cómo lo sabe?

-Porque lo estoy viendo por la ventana.

-Deje de ser exagerado, usted todavía tiene guayabo ${ }^{18}$ - le dijo ella, mientras se acercaba a su lado a mirar.

Escucharon algo parecido al rugir de un león. Se abrazaron como si el cuerpo del otro fuese el único resguardo. Los 140 kilómetros cuadrados de la superficie de Armenia, capital del departamento colombiano del Quindío, se sacudieron. "Virgen, ampáranos", rogó Mercedes, y sintió un dolor en el vientre.

En ese entonces Alejandra, la mayor de los cuatro hijos de Mercedes y Diego, tenía once años y no estaba en la casa familiar. Se encontraba con dos de sus hermanos y varios primos en el jardín infantil. Su padre le había dado dinero para

\footnotetext{
${ }^{17}$ Todos los nombres de la familia han sido cambiados por razones de protección. ${ }^{18}$ Resaca.
} 
que fueran al "circo pobre". Cuando Alejandra estaba a punto de salir del jardín -que no era otra cosa que una vivienda adecuada para recibir niños-, vio cómo el asfalto de la calle se movía en ondas.

Los niños notaron el movimiento del piso y el crujir de la casa y gritaron, querían correr. Alejandra se ubicó en la puerta y no los dejó salir: "Yo no sabía qué pasaba, pero por lo que veía, era peor si salían que si se quedaban adentro".

Las intenciones de la familia de radicarse en Panamá se suspendieron en aquellos 28 segundos que duró el terremoto de 6,4 grados de magnitud en la escala de Ritcher. Diego llevaba dos años vendiendo joyas, ropas, perfumes y zapatos procedentes de Panamá, y aunque no le iba mal, 1999 era un año de recesión económica para Colombia. Había un desempleo del $22 \%$ y el Producto Interno Bruto iba en descenso ${ }^{19}$. Panamá les ofrecía estabilidad económica.

Dos días antes del terremoto, Mercedes y Diego se habían despedido de sus familiares y amigos. Ese año, la Alcaldía de Armenia había adelantado las fiestas populares para enero. Algunos familiares se molestaron por los excesos de la pareja, como la ingesta de alcohol hasta el amanecer. Pero Mercedes y Diego estaban convencidos de que el 23 y el 24 de enero eran los últimos momentos que iban a compartir con todos los parientes.

El día del terremoto, al terminar de sacudirse la tierra, Diego y Mercedes abrieron los ojos. Vieron las paredes laterales inclinadas sobre los muebles de la sala y cada rincón del apartamento cubierto de polvo. Sólo quedó firme el piso donde estaban de pie y sus nombres en los gritos del hermano de Diego, que los pronunciaba desde la planta baja.

El sismo afectó a 28 municipios del eje cafetero colombiano. Armenia, a 290 kilómetros de Bogotá y con una población cercana a los 280 mil habitantes, fue la ciudad más devastada. Según la Comisión Económica para América Latina y el Caribe, CEPAL, la cifra total de muertos ${ }^{20}$ fue de $1.185^{21}$.

\footnotetext{
${ }^{19}$ Torres, Alejandro. La crisis colombiana de finales del siglo XX ¿un choque real o financiero? Perfil de Coyuntura Económica. $\mathrm{N}^{\circ} 18$, diciembre de 2011. Universidad de Antioquia. P. 82

${ }^{20}$ Esta cifra fue considerada sólo para los cadáveres reconocidos por sus familiares. Se estima que hubo 8,523 heridos y 731 desaparecidos en la totalidad de los municipios.

${ }^{21}$ Cepal. (17 de abril de 1999). El terremoto de enero de 1999 en Colombia: Impacto socioeconómico del desastre en la zona del Eje Cafetero. Recuperado de: http://www.cepal.org/publicaciones/xml/6/10136/colombia.pdf. P. 9
} 
A Diego en un principio le molestó la ropa que le prestó su hermano, más bajo y delgado que él. “¿Tener que ponerme esto yo?”, se quejaba. Hoy, cuando Mercedes recuerda, le causa risa lo apretado que se veía su esposo. En ese momento, su preocupación era saber cómo estaba su segundo hijo, Carlos, que veinte minutos antes del terremoto, se había ido a la casa de su abuela.

Así que aquel día, ellos y sus tres hijos iniciaron un recorrido por la ciudad para saber de Carlos. Vivían en el barrio Las Palmas, parte de la zona céntrica más afectada por el terremoto, mientras que la vivienda de la mamá de Mercedes quedaba en las afueras. Lo que vieron durante el periplo fue tan impactante que Alejandra no lo recuerda. Hace un esfuerzo por rememorar ese instante, sólo le viene a la memoria el dolor en los pies, el malestar de su primer período menstrual y un perro que no paraba de aullar.

A las 5:40 p.m. de esa tarde, un tramo del camino por donde pasaban se desmoronó con la primera y la más fuerte de las 138 réplicas que hubo ese mes. El segundo temblor fue de 5,8 grados en la escala de Richter y terminó por abrir las grietas.

Llegaron a las siete de la noche a la casa de los abuelos maternos. Sintieron alivio: todos los familiares estaban bien. Faltaba la hermana de Mercedes, que trabajaba en la terminal de transporte. Ella llegó, más tarde, con la ropa rasgada y una mezcla de sangre y polvo esparcida por el cuerpo semidesnudo. Dos mil metros cuadrados de la terminal habían quedado destruidos. Debajo quedó sepultada la caja fuerte donde estaban los primeros tres tiquetes a Panamá y toda la inversión en mercadería para abrir un negocio allá.

El entonces presidente de Colombia, Andrés Pastrana Arango, declaró la emergencia social, económica y ecológica en el Quindío. A la ciudad no llegaban alimentos, en varios sectores no había agua ni luz y los sobrevivientes eran nómadas en busca de sus familiares. Se reforzó el personal de la Policía Nacional para contener más a las personas sin dinero que intentaban salir de la ciudad $^{22}$, que a los saqueos. "Eso fue el segundo terremoto" dice Mercedes ${ }^{23}$.

\footnotetext{
${ }^{22}$ El Tiempo. (Enero 31 de1999). Sismo, Vándalos y Éxodo en Armenia. Recuperado de: http://www.eltiempo.com/archivo/documento/MAM-879361

${ }^{23}$ En el 2014, el Estado colombiano fue condenado por falta de planeación de las autoridades para evitar que habitantes de otros municipios saquearan la ciudad.
} 
Desde la primera noche del sismo, la carpa del "circo pobre" sirvió de alojamiento y sus animales fueron vistos como presas apetecibles ante la escasez. A los pocos días, creció el miedo a una posible epidemia por el hedor de los cuerpos insepultos. La familia se trasladó en un camión a Cali, donde una hermana de Diego.

\section{Un albergue en el abandono}

Después de un mes, creyeron que ya "había pasado lo peor" y regresaron a Armenia. La ciudad seguía en ruinas. En varias zonas se habían instalado albergues temporales. La situación era conflictiva: filas interminables para recibir los alimentos, casos de violación sexual a niñas, baños públicos y agua potable insuficientes.

En el albergue donde se asentaron convivían con otras 700 familias. Primero fueron carpas, luego la casa fue de bahareque ${ }^{24}$ y más delante de guadua ${ }^{25}$. Todo eso ocurrió en año y medio. Alejandra, la hija mayor, hoy cree que en aquellos días "creció de golpe". Cuidaba de sus hermanos pequeños, ayudaba a su mamá a cocinar con leña y era la encargada de traer el agua: "Subir la colina, bajar otra, llenar el balde y después a la venida otra vez caminar. Era agotador".

Con el tiempo a Diego le tocó ser un líder en la zona. Su vida había estado llena de adversidades que enfrentó con el liderazgo. Inició un censo comunitario y organizó a la población en siete sectores. Como las demandas de la comunidad eran cotidianas y complejas de priorizar, se propuso la elección de un presidente. Él se postuló como vice. En la contienda también participaron algunos jóvenes que acaparaban las ayudas. Al final, fueron ellos quienes eligieron "a dedo" al presidente y amenazaron de muerte al resto de los candidatos. "Uno creía que los paramilitares ${ }^{26}$ eran del campo, ahí nos dimos cuenta que no", dice Mercedes.

\footnotetext{
${ }^{24}$ Material de vivienda construida con palos unidos, que en vez de cemento llevan barro.

${ }^{25} \mathrm{El}$ tronco de una planta parecida al bambú, pero más delgada.

${ }^{26} \mathrm{~A}$ finales de los 60 y de acuerdo a la lucha "contra el comunismo" con el decreto 3398 de 1965, que luego pasaría a ser la Ley 48 de 1968, se dio soporte jurídico a los grupos de autodefensas asistidas por las Fuerzas Armadas. De este modo, los 70' sería una época de expansión paramilitar en varias zonas rurales donde terratenientes pretendían defender sus riquezas e ideología con el apoyo armamentista del Ejército Nacional. En los $80^{\prime}$ se incrementaría esta expansión con el apoyo de ganaderos y narcotraficantes. Para los 90 se agrupan todas las organizaciones paramilitares y conforman las Autodefensas Unidas de Colombia, AUC, consolidadas como una estrategia paraestatal contrainsurgente. Pero más allá de combatir a las guerrillas, estos grupos perseguían, torturaban, desplazaban y masacraban de forma individual o colectiva la población civil que quedaba en medio de las disputas y a los líderes,
} 
Los jóvenes, después de las intimidaciones, desplazaron a los líderes y controlaron el barrio.

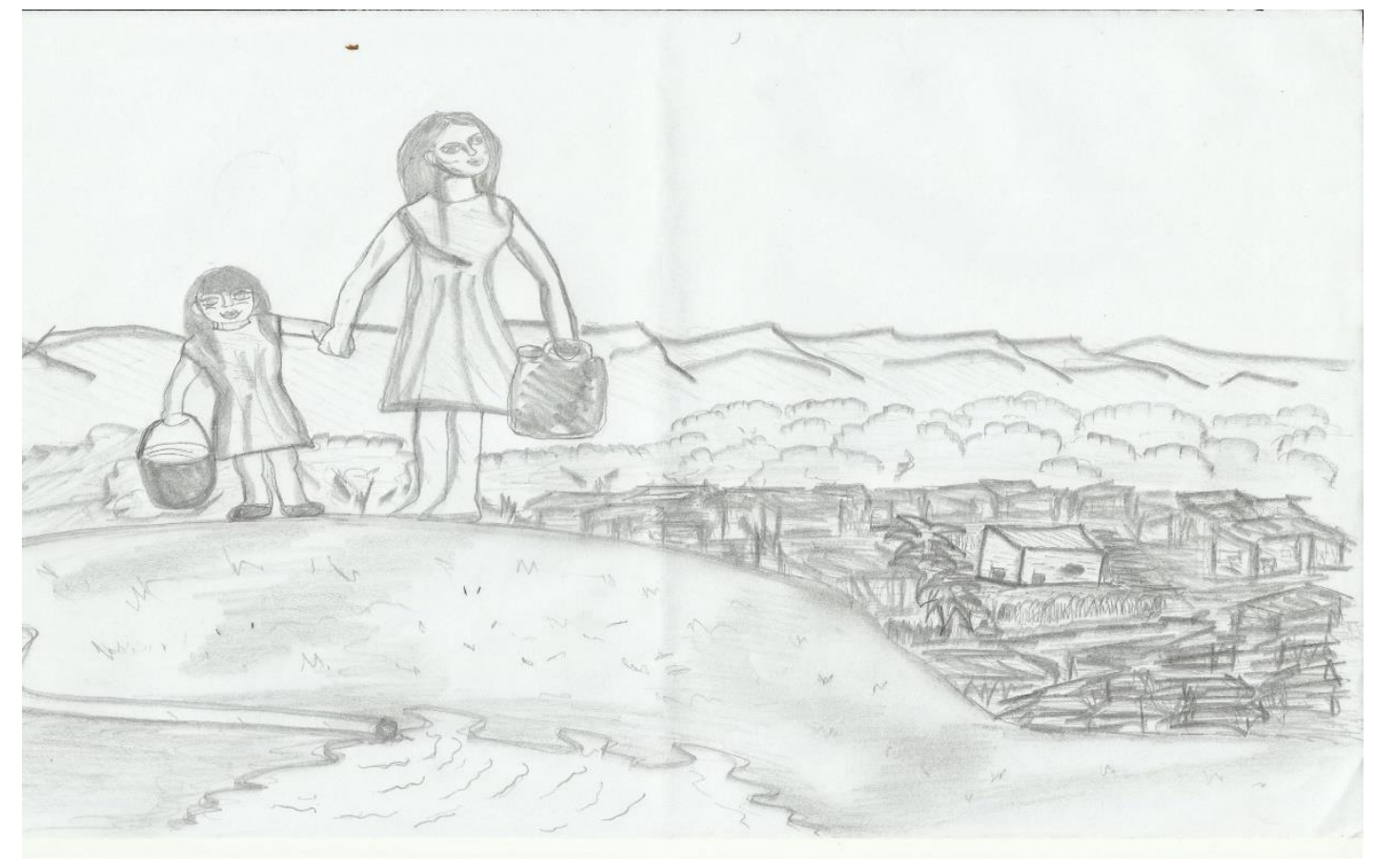

Recuerdo alusivo al albergue. Dibujado por Alejandra, hija mayor.

\section{Vereda ${ }^{27}$ Buenos Aires: $12,4 \mathrm{Km}$ recorridos}

Cuando el albergue se fraccionó, por seguridad, Diego se alejó de los compromisos sociales y se dedicó a la artesanía. Desde un par de años antes del terremoto, la pareja abonaba dinero para la compra de un terreno en zona rural. En el 2001 resolvieron forzosamente mudarse al campo.

Un camión se llevó lo poco que tenían para el corregimiento Buenos Aires, también en el Quindío. Soñaron que allí comenzarían una vida más tranquila. Lo primero que experimentaron fue el frío y lo lejano que se divisaba la ciudad.

\footnotetext{
señalados como "colaborador de las guerrillas". A mediados de los 90, en el último año presidencial de César Gaviria se avalaron las Asociaciones Comunitarias de Vigilancia Rural, Convivir, mediante el decreto 356 de 1993 para trabajar labores de inteligencia militar junto al Estado. Cinco años después serían catalogados de inexequible, pero para ese momento estos grupos extendieron el paramilitarismo ya había logrado un auge difícil de desmantelar, pues contaban con el apoyo de altos mandos del ejército, gobernadores, ministros, concejales y congresistas, en lo que años más tarde se llamó "la parapolítica". Para esta misma época los paramilitares estaban fortalecidos e incursionan en las ciudades y en la mayoría de las instituciones estatales. Durante el gobierno de Álvaro Uribe Vélez, se desmovilizan, desde el 2003 al 2006, los bloques de las AUC en el proceso de Justicia y Paz con penas máximas de ocho años. A partir de estos años hubo una reconfiguración del paramilitarismo con otros nombres, el Estado los llama Bandas Criminales, BACRIM.

27 División territorial rural anterior a los municipios. También se le conoce como caseríos.
} 
Lejanía que se agudizaba porque no había electricidad, ni médicos, ni escuela y el único lugar donde llegaba el agua era al frente de su nueva casa.

A Buenos Aires siempre la cubría una neblina hasta el mediodía, en la tarde todo se despejaba y se podían ver las montañas verdes y, a un extremo más lejos, la punta de los nevados. En esa época, el territorio estaba habitado por cien hogares dispersos y todo a lo que debían tener derecho había que gestionarlo.

Era una situación idéntica a la que había presenciado Diego cuando tenía 17 años. En 1984, se había ido a trabajar la tierra en el caserío Monserrate, en el departamento del Caquetá, al suroriente de Colombia. Allí lo habían elegido secretario de la Junta de Acción Comunal: era el único que sabía leer y escribir. Con ayuda de la comunidad, adecuó una casa abandonada para que funcionara como escuela, delegó un enfermero para la vereda y le propuso a su jefe reemplazar los cultivos de coca por semillas de plátano y yuca.

En ese mismo año se formó el partido político Unión Patriótica, donde Diego militó. Cuando el partido tuvo auge, en toda Colombia empezó su exterminio. "A través de los medios, se mostraban los asesinatos de los reconocidos, pero nadie mostraba lo que vivíamos nosotros en el campo. Por ejemplo, que en el río Caguán bajaban cantidades de muertos". Diego se desplazó a Bogotá a finales de 1989. Las masacres que vio en Caquetá lo aleccionaron. Estuvo ocho años con miedo a salir a la calle, a relacionarse con desconocidos. Aprendió a quedarse callado y a no participar en asuntos colectivos.

Las circunstancias de la vereda Buenos Aires llevaron a Diego a posicionarse una vez más como líder. Diseñó una rejilla artesanal que retenía la arena para que el agua fuese más limpia. Motivó a los vecinos a abrirse camino entre la maleza, y con ayuda de Mercedes insistió en la alcaldía hasta obtener el permiso de instalar la luz en la vereda. Con el mismo método, él y los vecinos lograron la construcción de una cancha de básquet y de una escuela.

En aquel momento, al principio, las Fuerzas Armadas Revolucionarias de Colombia (FARC) ${ }^{28}$ eran la única presencia de autoridad en el territorio. Operaba

\footnotetext{
${ }^{28}$ En 1964 las FARC nacen como "guerrillas móviles", después de que el gobierno de Guillermo León Valencia, con la asesoría norteamericana, decidiera enfrentar Marquetalia, una de las zonas donde operaban "comunistas". Luego se convirtieron en "guerrilleros revolucionarios de corte marxista-leninista", que pretendía defenderse de los terratenientes, la oligarquía colombiana y oponerse a la intervención de los Estados Unidos en asuntos internos. Idearon
} 
el Frente ${ }^{29} 50$ al mando del comandante alias 'Enrique'. Una noche sus integrantes llegaron hasta la puerta de la casa rural de la familia.

-Toc, toc, toc.

-Buenas noches. Es que vamos hacer una reunioncita porque afuera está haciendo mucho frío.

-Y aquí trajimos panelita ${ }^{30}$, ¿nos hace café?

"¿Y quién les dice que no? Yo les servía, pero muy distante. Me cuidaba de ellos”, se excusa Mercedes. La finca estaba en un lugar estratégico: desde allí se podían observar los terrenos en los cuatro puntos cardinales.

En el 2002, llegó el Ejército Nacional. Para entonces, el sustento de la familia era la venta de comida típica como empanadas o agua panela con queso, y de artesanías de la región hechas en madera: réplicas de vasos, lámparas y cofres. Se ubicaban en la orilla del Alto de la Línea, carretera que comunica al Quindío con el centro del país. Para poder estudiar el bachillerato, Alejandra vivía en la casa de sus abuelos maternos en Armenia y los fines de semana, viajaba a vender las artesanías con su hermano Carlos.

En un lapso de 10 días el Ejército Nacional les dio dos avisos verbales para que dejaran de vender en ese lugar. Alejandra hoy recuerda no haberlos comprendido bien. "Lo que entendí era que le tapábamos la vista al enemigo, les estorbábamos". Una semana después del último aviso, el Ejército volvió a acercarse al kiosco y los acusó de ser "informantes de la guerrilla". Ellos no

\footnotetext{
procesos políticos y militares para llegar al poder, que se fortalecieron en los años 70 con una apuesta hacia lo nacional con la organización estratégica de Frentes y el apoyo del Partido Comunista Colombiano. Durante los 80 se perfeccionan tácticas de ofensivas, sumadas a prácticas de extorsión en zonas de cultivos ilícitos y secuestros como forma de financiamiento, que ayudaron a la renovación armamentista. En 1984 la propuesta política de las FARC estuvo consagrada en el partido Unión Patriótica como acuerdo de los diálogos de paz con el presidente Belisario Betancourt, pero sus integrantes fueron exterminados. En 1991 se realiza una mesa de diálogos con el mandatario César Gaviria que fracasarían un año más tarde, tras el secuestro y muerte de un ex ministro. En 1998 se abre otra posibilidad para la paz con la mesa de negociación por tres años con el presidente Andrés Pastrana en una zona de distención. Sin embargo, los diálogos permanecen en contante tensión, pues para el 2000, el Plan Colombia, dirigido por los EE UU, intensifica los planes contrainsurgentes, el accionar de los paramilitares se encuentra en la cúspide y parte del cuerpo militar estaba en desacuerdo con despeje, por su parte la guerrilla sigue en ataques de defensiva y ofensiva. Todo esto termina por levantar los diálogos. A partir del 2008, se intensifican los bombardeos que terminan con parte del secretariado de la guerrilla, lo que lleva al grupo a replegarse. Desde el 2012 están en diálogos de paz con el presidente Juan Manuel Santos.

${ }^{29} \mathrm{La}$ guerrilla de las FARC está conformada por frentes, que son unidades de combates con aproximadamente 1000 guerrilleros que operan en zonas específicas. Las FARC tienen 70 frentes.

${ }^{30}$ Producto derivado de la caña de azúcar, que se usa para endulzar.
} 
supieron qué querían decir, pero por sus caras dedujeron que era grave. Les pidieron los documentos de identidad, no los tenían. Alejandra era una adolescente de 14 años y su hermano tenía 13.

-Vengan con nosotros. - les dijo un militar

-Pero, ¿por qué tenemos que irnos con ustedes? - respondió Carlos ${ }^{31}$

-Ah, si estás tan alzadito ${ }^{32}$, jentonces pelea!

Un soldado empujó a Carlos, que rodó por el barranco entre la maleza. Un alambre de púas lo hirió en la pierna derecha. Alejandra se fue con los uniformados. No recuerda haber visto lo sucedido con su hermano. Cree que él iba caminando detrás de ella. Su única preocupación eran las artesanías, las habían dejado solas: "Mi mamá nos podía regañar".

Los vecinos se dieron cuenta de lo que había pasado, reclamaron por Alejandra y buscaron a su hermano. Ambos estaban nerviosos y confundidos: "Lloramos. Eso nos quedó para siempre, hasta hace poco recordaba el apellido del teniente. Uhm, creo que era Aguirre", dice Alejandra.

La familia asumió esas acusaciones como una advertencia del Ejército. Como el conflicto es ciego a las paradojas que crea, la familia Mejía Salazar ya le huía a la guerrilla. Las FARC se percataron del liderazgo de Diego. Lo presionaron para que consiguiera medicamentos, y lo que logró fue llevar a un médico a la zona una vez por semana.

Mercedes reconoce que luego del terremoto, en el albergue en Armenia la guerrilla les prestaba dinero para ayudar a solventar las necesidades. Asegura que se trataba de un préstamo, que siempre pagaron, porque "sino, sería comprometerse". Una noche se presentó una jefa guerrillera. Con un diálogo amable y frío, destacó el compromiso de la pareja con la comunidad y le informó a Mercedes que debía entregar a sus hijos mayores "a la causa" para que fueran "unos verdaderos líderes".

\footnotetext{
${ }^{31}$ Carlos es el único hijo de la familia que le ha costado acceder a las entrevistas. Sólo se atrevió a contar este episodio en una conversación.

32 Para decir que alguien está a la ofensiva.
} 
Mercedes sólo alcanzó a decir que hablaran con Diego. Durante semanas, él hizo malabares para no encontrarse con ellos: cortaba camino, llegaba tarde, dormía en otra casa. Hasta que una noche lo encontraron. Reiteraron: querían a sus hijos mayores, a ellos les parecía que ya era hora de que empezaran a ir al campamento.

Luego de esa "propuesta", Diego se llevó a sus dos hijos mayores a Armenia. En la casa quedaron Mercedes y los más pequeños -de cinco, cuatro, tres y dos años de edad, y el bebé de ocho meses-. Por tres días, Mercedes mintió a los vecinos, les decía que el padre se los había llevado porque se habían aburrido de "lo rural". Como estaba sola, no podía hacer comida para vender, abandonó el kiosco y se lo cedió a una vecina.

Sentía angustia de estar lejos de su esposo e hijos mayores. No tenían casi comunicación. Y de ella dependía salvar a los niños. Su plan sería engañar a la guerrilla y conservar la calma para que no sospecharan del objetivo: se escaparía.

Mercedes le dijo a Luis, uno de los ayudantes de la guerrilla, que el bebé estaba enfermo. Él se ofreció a llevarla al Hospital de Calarcá. Hizo una maleta y dijo que empacaba la grabadora para que los niños no se aburrieran.

A la entrada del hospital, no le costó fingir preocupación con el bebé en brazos y los otros cuatro a lado y lado. Sus gestos nerviosos y torpes no desentonaban con la atmósfera hospitalaria.

-Muchas gracias. Aquí me van a demorar. Si alguna cosa, yo lo llamo.

-Me llama entonces para venir a buscarla.

-Sí claro, lo llamo.

Sintió las palpitaciones más seguidas. Sus oídos esperaban escuchar el sonido del motor de la camioneta.

-Señora, ¿cuál es el motivo de la emergencia?

Se le ocurrió consultar por el asma de su cuarto hijo. Mientras lo decía, interrumpió el rezo mental donde suplicaba que el señor Luis se fuera. 
A los diez minutos escuchó cómo encendía el vehículo y aceleraba. No esperó a que la atendieran. Durante media hora, recorrió el hospital, entre rezos y vueltas de cabeza. Salió por otra entrada y subió a un taxi hacia la casa de sus padres en Armenia.

Tardó tres días en reponerse del susto y reunir las fuerzas para denunciar los hechos en la Fiscalía General de la Nación, donde creyó que le podrían hacer seguimiento al caso. Alejandra hoy dice que pensar eso fue "muy inocente". Allí no aceptaron su declaración porque en una parte responsabilizaba al Ejército Nacional y para esa entidad, Mercedes estaba confundida: "El Ejército no hacía esas cosas".

Entonces, se dirigió a la Procuraduría Provincial de Armenia, donde le tomaron la narración de los sucesos, pero sin anotar el episodio con el Ejército. Así, la familia Mejía Salazar ingresó al registro de desplazamiento interno forzado. Según cifras del Departamento para la Prosperidad Social, vivió junto a otras 86.487 familias colombianas el primer momento de expansión de este fenómeno, que se dio entre 1998 y 2002.

En 2002, cuando la familia llegó Armenia, el presidente Pastrana y la Iglesia Católica inauguraron varios proyectos de vivienda como el del barrio El Jubileo, al que ingresaron con el aval estatal de "desplazados por la violencia" y con la historia menos oculta de ser damnificados por el terremoto.

En el barrio, Diego era uno de los pocos habitantes del sector con empleo, vendía mercancías en la terminal. Otra vez la desigualdad social estaba presente como en los años del albergue. Alejandra recuerda: "Nunca vi la pobreza como la vi en ese barrio". Mercedes y Diego no fueron indiferentes. Parecía que las tristezas padecidas en sus infancias se hubieran convertido en impulsos humanitarios para disminuir las desdichas de los jóvenes y niños.

Diego había quedado huérfano de madre siendo un recién nacido. La militancia armada de su padre, hizo que su abuela materna lo criara en el campo. La infancia transcurrió arando la tierra y cargando bultos. Su padre lo volvió a ver cuando Diego tenía 14 años. Lloró. No encontró un niño ni un adolescente sino un cuerpo fornido, las manos de labrador, la pinta de campesino y los ademanes de adulto, como si siempre hubiese sido un hombre grande. Hoy el físico de 
Diego es el de alguien rudo, pero se diluye con sus movimientos dinámicos. Parece un niño corredizo. Tiene un tono fuerte, respetuoso y jovial. Interroga, planea y se admira con gestos ingenuos. Años después, algo de eso deben encontrar los niños en situación de calle en Quilmes, Argentina, que confían en él 33 .

Mercedes tiene una teoría familiar. Cree que fueron pobres no por falta de recursos sino de perspicacia materna. Existe cierto reproche y al tiempo agradecimiento. No tendría la entereza que la caracteriza, si desde su niñez no hubiese tenido que ir a buscar alimentos para su casa. En su juventud, por instinto aprendió a cuidarse. Formó un carácter fuerte que le ha servido para enseñar a vivir a sus nueve hijos e ingeniárselas para enfrentar la discriminación. En su adolescencia soñó con ser enfermera, hoy sus manos tejen, cocinan y curan para mantener a su familia.

\footnotetext{
${ }^{33}$ En la actualidad, es operador social en la Subsecretaría de apoyo a la infancia y adolescencia en la Municipalidad de Quilmes, provincia de Buenos Aires.
} 


\section{Trabajo comunitario}

La situación en el barrio El Jubileo en Armenia era compleja. "Nosotros no podíamos vivir así. Comernos un plato de fríjoles y los otros nada", dice Alejandra. Sus padres adecuaron la casa para un taller de guadua, al que asistían jóvenes sin empleo, y abrieron un comedor comunitario para niños "los días más críticos", miércoles y domingos.

Primero iban diez, luego veinte y terminaron el año dando de comer a entre 120 y 150. "Amigos del trabajo en la terminal de transporte me llevaban verduras para compartir", recuerda Diego. A veces se hacía por más de dos días y sólo era "avisarle a uno y ya llegaban todos, hasta traían tazas para llevarle a los adultos".

Desde la mañana, Mercedes y Alejandra preparaban los ingredientes y les pedían a los niños que llevaran el plato y los cubiertos. Ellos disfrutaban ese momento, se sentaban en las escaleras del frente de la casa a jugar y a comer. Por esos días, las sonrisas de satisfacción opacaban lo hostil de su entorno. En diciembre, con la natillada ${ }^{34}$, el regocijo era mayor.

Luego de diez años fuera del país, Mercedes no duda en afirmar que lo que más extraña de Colombia no es la familia ni la comida sino "mis 150 niños". Su rostro se transforma cuando recuerda sus historias. Por ejemplo, la de "Chinga", tiene la imagen intacta de la primera vez que fue a su casa a almorzar con un revólver calibre 38 en el cinto.

Imita la voz de adulto que ponía "Chinga":

-Oiga señora, y usted ¿por qué da almuerzo?

-Porque quiero.

-Y ¿cobra?

"Pero me lo decía, así como un viejito". Mercedes sujeta sus manos en la cintura en posición desafiante:

-No.

${ }^{34}$ Postre de navidad para compartir. Típico en todas las regiones de Colombia. 
-Ah, porque yo creía que cobraba.

Tenía ocho años, su madre y abuela estaban en la cárcel acusadas de microtráfico de drogas. Siempre andaba armado, hasta que Mercedes le dijo que para comer en su casa no necesitaba el arma. Nunca más la llevó.

Ahora, Mercedes se pregunta por el destino de Chinga: "pobre criatura, yo creo que ese niño ya se perdió". Se le humedecen los ojos, aunque sus ojos siempre están brillando. Hay que verlos de cerca e intentar que sus pómulos elevados no los opaquen. La sonrisa de añoranza los resalta y los vuelve a hundir. Se queda en silencio y luego, como cavilando en voz alta, dice intranquila: "A veces pienso y ¿si nos hubiésemos quedado? Tal vez hubiéramos podido salvar a alguno".

Desde el 2002, los asesinatos, amenazas y desapariciones en el barrio fueron menos esporádicos. A mediados del 2005, hombres de civil y armados convocaron a los líderes comunitarios. Hablaron de la reelección de Álvaro Uribe Vélez ${ }^{35}$, dejaron claro que ellos estaban con él y que debían "colaborar" para que saliera electo. A Diego le encomendaron la tarea de persuadir a los padres de los niños, que iban a almorzar a su casa, de votar por Uribe. Él no aceptó.

La negativa rebasó la paciencia del grupo paramilitar. Ellos venían haciéndole seguimiento a los comportamientos de Diego: un taller donde se escuchaba música protesta y ocupaba a los jóvenes desempleados, un comedor que lo posicionaba como líder solidario y el plantón novedoso en el que sepultó su cuerpo por más de 24 horas $^{36}$ para impedir el desalojo de sus vecinos.

\footnotetext{
${ }^{35}$ Fue presidente de Colombia en el período 2002-2006. Llevó a cabo una reforma constitucional para ser reelegido de manera inmediata por los siguientes cuatro años (2006-2010), como ocurrió. Aunque durante su carrera política perteneció al Partido Liberal, cuando se lanzó a la presidencia se alejó de este partido, pues éste contemplaba continuar con los diálogos de paz con las FARC, decisión contraria a la postura e ideología de Uribe, quien luego de la muerte de su padre en manos de la guerrilla en 1983, se propuso derrotarlas. Por eso, como gobernador del departamento de Antioquia (1995-1997), apoyó la presencia de Convivir en su departamento. De ahí que, su Política de Seguridad Democrática, se encargaría del fortalecimiento de las Fuerzas Armadas y de la asesoría tecnológica y militar de los Estados Unidos para bombardeos a campamentos guerrilleros, incluso fuera del territorio. En su segundo período se intensifican las estrategias para exterminar a las FARC, a la vez que aumentaba la población desplazada, la persecución a estudiantes, sindicalistas, campesinos y líderes, que se oponían al gobierno o interfirieron con los métodos de reconquista del Ejército a los territorios dominados por las FARC. A esto se le sumaron las violaciones a los Derechos Humanos como las ejecuciones extrajudiciales, en las que se asesinaban a campesinos o jóvenes en situación vulnerable, las intercepciones telefónicas a políticos de oposición, magistrados y a periodistas. Antes de finalizar su segundo mandato se desmanteló el tráfico de influencia y dádivas a congresistas para votar la reelección presidencial, que le permitió a Uribe estar en el poder durante ocho años. Tiempo en el cual el paramilitarismo permeó con más fuerza los poderes ejecutivo y judicial. De ese panorama quedaron nueve funcionarios de su gobierno condenados, diez con procesos judiciales abiertos y un prófugo de la justicia. Actualmente es senador de la República de Colombia y lidera el partido de oposición Centro Democrático, 2014-2018.

${ }^{36}$ Periódico El Tiempo. (7 de julio de 2004). Enterrados hasta el cuello. Recuperado de: http://www.eltiempo.com/archivo/documento/MAM-1569097
} 
Esas irreverencias lo convirtieron en un objetivo militar. Además, su hermano, estando ebrio dijo en público que se sentía orgulloso de su padre por haber hecho parte de las FARC en sus inicios. Esta imprudencia afectó a la familia y a parte de la comunidad. Un día "patearon" la olla donde cocinaban los alimentos para los niños y les dijeron que no debían encargarse de esas actividades porque le competían al presidente Uribe. Fue el fin del comedor comunitario y del taller.

Diego dejó el empleo. La comunidad ya lo había defendido de un intento de atentado, luego de eso se emplazó en su casa para protegerse. A Mercedes le tocó trabajar de comerciante en Bogotá. Se comunicaban todos los días por teléfono. Una tarde, Mercedes escuchó en una llamada tiros de ametralladora, uno detrás de otro. Le disparaban a la fachada de la casa. Todos estaban en el patio. Se tiraron al piso y sobrevivieron.

El Ejército también llegó al barrio, patrullaba y hacía allanamientos. La situación de peligro inminente los condujo a crear estrategias de escape. Diego delegó a su hijo Carlos de 16 años la responsabilidad de informar si "pasaba algo grave". Él debía saltar la pared del patio, llegar a la esquina, usar el teléfono público y avisar a su tía Elvira.

Alejandra recuerda el año 2005 como el peor de su vida: "Irme al colegio y pensar que estaban mis hermanos solos con mi papá. Era un nerviosismo constante. Salir del colegio y pensar que podía estar alguien esperándome, porque ya en ese momento se empezó a escuchar de personas que desaparecían". A su casa llegaron tres panfletos con ultimátum de muerte.

Mercedes regresó a Armenia. La señora que le cuidaba a los niños le dijo: "los conservadores somos los que tenemos que vivir en este país. Ustedes se tienen que ir, no cabemos todos juntos". No sabían para dónde ni cuándo, algunos morrales ya estaban listos. También tenían cartas de organizaciones donde constaba que Diego era un líder. Él lo resume así: "Lo traumático es el momento en que te amenazan. Cuando uno programa la huida, es como cuando vives en una casa ajena y sabes que tarde o temprano te tienes que ir". 
El vecino del frente, Cristian, era un joven cercano que trabajaba para uno de los comandantes de los paramilitares del Magdalena Medio, Juan Ramón Isaza. Durante una crisis de pareja, Mercedes y Diego le dieron consejos y cuando su esposa lo abandonó, como pudieron, lo ayudaron a afrontar la soledad.

Una noche se quedó hasta tarde en su casa, incluso después de la cena seguía en el sillón de la sala pensativo. Mercedes organizó la cocina, llevó a dormir algunos niños. A Diego ya se le habían agotado los temas de conversación con Cristian. Él seguía ahí. "Noté que no se quería ir", recuerda Mercedes.

-Yo no sé cómo decirle -pronunció Cristian, en actitud de niño arrepentido.

-Dígame-Diego buscó mirarlo a los ojos.

- Yo lo aprecio mucho. Me mandaron a matarlo, sino me matan a mí.

Hubo una pausa.

- Yo lo he pensado bastante y no soy capaz, güevón. Les doy tiempo para que se pierdan de por aquí. Digo que no los encontré. ¡Pero váyanse ya! 


\section{Parte \\ Chile, un destino inconcluso}

En 2006 Diego lo sabía: sería perseguido en cualquier lugar de Colombia. "La vida es más valiosa, había que protegerla, no podíamos exponernos más". Su familia volvió a enfrentar el segundo momento de expansión del desplazamiento interno forzado, entre 2005 y 2007 . Ellos fueron uno de los 95.662 hogares víctimas, según cifras del Departamento para la Prosperidad Social.

Luego de llegar por ocho días donde su hermana en Cali, Diego se comunicó con un amigo en Chile para emprender otra huida. Sentía más nervios, resentimientos y dudas que las demás veces, pero estaba seguro: Sería la salvación de la familia.

\section{Tacna, Perú: 4.034,1 Km}

La pareja y sus siete hijos cruzaron la frontera con Ecuador el 17 de marzo de 2006. El país al que acababan de llegar atravesaba la primera semana de una huelga social. Campesinos, educadores, indígenas y estudiantes se unían para protestar por la firma del Tratado de Libre Comercio con Estados Unidos, promovido por el gobierno de Luis Alfredo Palacio. El transporte público era un caos y no querían venderles comida. El plan de viaje para llegar por vía terrestre a Chile en menos de veinte días, cambió.

Debido al paro se quedaron en Tulcán, Ecuador. Después de más de quince días se enteraron que un colectivo esquivaba los bloqueos, atravesando la selva de la Provincia de Esmeralda hasta Huaquillas, en la frontera con Perú. Diego y su familia tenían dolor de estómago. "En Perú siempre tuvimos sed", recuerda Alejandra.

Ese 3 de abril, al descender del vehículo en Tumbes (Perú) una marea humana se abalanzó sobre ellos y se tragó tres maletas con ropa, el televisor y la mayor parte del dinero que llevaban para todo el viaje.

Aun así, en dos días lograron continuar a Lima. La sede del Alto Comisionado de las Naciones Unidas para los Refugiados (ACNUR) los ubicó en una casa 
colonial y espaciosa para a solicitantes de asilo. Convivieron con dos musulmanes que rezaban cinco veces al día, algunos colombianos sin familia y un croata que decía "Pum, Pum, papá muerto, mamá muerto" y dibujaba en el aire sonidos y señas.

A ellos también les tocó contar parte de su historia y disipar dudas sobre su pertenencia a algún grupo. Otros refugiados les habían contado que a otro albergue, el Santa Rosa en Quito, Ecuador, lo ocupaban ex guerrilleros y paramilitares que se atrincheraron en las habitaciones hasta que la policía se los llevó presos. En este albergue en Lima también fueron sometidos por los paramilitares. Sus habitantes temían que sucediera una nueva disputa. Antes de su llegada se rumoró: venía "una pareja de guerrilleros con sus siete hijos" 37.

Transcurrió un mes entre la venta de artesanía y las diligencias para que el ACNUR les diera los status de refugios. A los dos meses de su estadía en Perú, la Fundación Ecuménica para el Desarrollo y la Paz, Fedepaz, los citó a una entrevista.

La trabajadora social del área de desarraigado de la entidad, Rosa Quedena ${ }^{38}$, los interrogó sobre los motivos del desplazamiento y también por los colombianos que habitaban el albergue de Lima. Como la Fundación tenía conocimiento de las personas que llegaban a Perú para refugiarse, sabía que el ex jefe paramilitar alias 'Jorge 40' había estado en el albergue ${ }^{39}$. La funcionaria los alertó: "Si él está cerca, están en peligro".

-Pero si ACNUR nos dijo que buscáramos casa y que a los niños los iba a poner a estudiar - replicó Mercedes.

-Y ¿por qué no se lo han dado?

-Bueno, porque dijeron que tenían que consultar con Bogotá.

\footnotetext{
${ }^{37}$ Anexo I. Diario del padre de familia.

${ }^{38}$ La funcionaria recuerda en el 2015 vía mail que "como estábamos en contacto permanente con los solicitantes de refugio y con otros actores claves en ese entonces, esto nos permitía tener elementos suficientes como para evaluar la situación de la familia y finalmente, mi evaluación fue que era muy riesgoso que la familia se quedará allí porque justo esta persona que había sido jefe paramilitar-'alias Jorge 40' - estaba en el mismo hospedaje, y existían serias dudas de que se hubiera desenganchado realmente de su grupo operativo".

${ }^{39}$ Anexo II. Diario del padre de familia.
} 
"Esa señora me miró con una compasión. Nos vio tan desprotegidos, tan inocentes, tan, tan de todo", dice Mercedes, quien ahora reconoce que la funcionaria estaba en lo cierto.

-No, es mejor que se vayan. Hubo otros casos así y los devuelven para Colombia. Yo les voy a dar los pasajes, pero díganme que sí se van a ir.

Dos días después retomaron su viaje a Chile, sólo con el nombre de una funcionaria de ACNUR en ese país, en la que la fundación Fedepaz sí confiaba. Estaban en el colectivo para cruzar Tacna, (Perú), y llegar a Arica, en el lado chileno, cuando un retén detuvo la marcha. Al parecer, un grupo de colombianos y peruanos llevaba droga en el colectivo de adelante.

Los policías pidieron la documentación de los niños. Ellos mostraron los registros civiles. No les creyeron que eran los padres porque los siete hermanos comparten pocos rasgos físicos en común. De nada sirvió que Diego les explicara que los hijos de los colombianos nacen así, "mezclados, no como a ustedes que todos les salen rubios o morenos".

Llevaron a toda la familia a la comisaría y luego a un hotel custodiado por la Policía. Se los acusó de un delito: tráfico de niños. "La salvación de nosotros fue un periodista", dice Mercedes. Además de llevarles comida, publicó en el Diario Correo su caso como Familia huye de Colombia y queda varada en Tacna. Así se logró que los habitantes se acercaran a darles provisiones y consejos: "No se queden en este pueblo porque pasan cosas horribles, a las personas las matan y las echan al desierto", les advertían.

Después de cinco días en el hotel, se contactaron con el Defensor del Pueblo de Tacna, Manuel Ricardo Amat. Él averiguó la situación de la familia con Fedepaz y con el consulado colombiano. Dedujo que la familia estaba en riesgo de ser deportada ${ }^{40}$. Habló de forma extraoficial con el cónsul de Bolivia. En tres días estaban en un colectivo con más contrabando que equipaje.

\footnotetext{
${ }^{40}$ En la actualidad Amat es Defensor del Pueblo en Arequipa (2015). En entrevista por correo electrónico aseguró que por el "por el transcurso del tiempo" no recordaba con exactitud los hechos que influyeron en su decisión para ayudar de forma extraoficial a la familia.
} 


\section{La Paz, Bolivia: 4.429,1 km}

El 3 de junio llegaron a Desaguadero, en la frontera entre Perú y Bolivia, a 112 km de La Paz. Encontraron dos ríos: el afluente homónimo del lugar y el formado por comerciantes con bultos de alimentos. Para evitar a los guardias cruzaron el primero cerca de las 5:30 am.

En Colombia se conoce como invierno a los meses de lluvia. En ese trayecto todos los integrantes de la familia sintieron el invierno real, el más frío y poco condescendiente con sus camisetas de algodón. Los padres quisieron hablar con el conductor de la canoa, pero el mal de páramo "congeló sus lenguas" y no pudieron vocalizar ni una sílaba. Sus hijos mayores acordaron cruzar con la canoa al otro lado del río por 60 bolivianos. Los nueve viajaron en dos embarcaciones, amontonados unos entre cilindros de gas y otros, entre garrafas de cervezas.

Alejandra, blanca, de cabello largo y negro como sus ojos, tenía 18 años. A medida que se alejaban de Colombia, su apariencia y la de sus hermanos llamaban más la atención. Antes de bajar del colectivo en Perú, el conductor le dijo a Mercedes que sus hijos eran muy bonitos, que los cuidara, se los podían robar. En el hotel donde estuvieron detenidos, un señor le preguntó a Alejandra si eran gitanos. Desde que entraron a Bolivia los empezaron a mirar con un gesto de burla, les decían "gringos".

Al llegar a La Paz, se dieron cuenta que era sábado. Diego asegura que en ese momento, Alejandra y él eran los más fuertes: "El resto estaba muy descompuesto, en mal estado". Entonces, fueron ellos quienes caminaron por 45 minutos las lomas de la ciudad para buscar dónde dormir. "Como eran cuadras empinadas, descansábamos, seguíamos, a veces nos apoyábamos el uno al otro o con las paredes". Todo estaba cerrado.

A Mercedes la habían dejado con los niños frente a la Catedral de San Francisco, al lado de un centro comercial. Destaparon la comida que el Defensor de Tacna les había empacado. Estaba rancia. El hambre opacó el sabor. "Es tan cierto el 
refrán que dice: para una buena hambre no hay comida mala", reflexiona Mercedes.

-Señora, no puede estar aquí, córrase - le ordenó un vigilante.

-Tranquilo que nosotros ya nos vamos.

-Se tiene que ir ahora - le reiteró.

A Mercedes se le subió a la cabeza la angustia de todas las veces que había "tenido que irse". Le contestó a los gritos:

-¡NO ME JODA, NO ME DIGA UNA MIERDA, NO TENGO PARA DÓNDE IRME!

El alboroto alarmó a dos colombianos de Cali que pasaban cerca. Les dieron gaseosas a los niños y le recomendaron a Mercedes acudir al Ejército de Salvación ${ }^{41}$, al mando de la "Mayora de Morales". No fue fácil, pero después de rogarle, de recibir acusaciones de ser delincuentes disfrazados de migrantes, de permanecer en la entrada de la casa por horas, de que la hija de la Mayora suplicara por ellos, Morales les retuvo los pasaportes y les permitió dormir por dos noches.

Todos estaban pendientes de los partidos de la Copa Mundial de Fútbol que se jugaba en Alemania. Ellos, en cambio, contaban las horas para ir a la oficina de Migración el lunes y solucionar su estadía en otro país. Durante ese tiempo, fueron despojándose de los pocos objetos de valor que les quedaban: trueque entre artesanías por empanadas, tres pares de aretes de oro de las niñas por leche, y un celular de pantalla de colores, moderno para la época, a cambio de lo que quisieron pagarles.

Luego de quince días en un hotel, llegaron los papeles que los certificaban como refugiados. Se fueron a un monoambiente estrecho en Tembladerani, un barrio que le debía su nombre a los temblores. Quedaba en el filo de una loma que hacía de la vista un mapa de la ciudad, incluso se veía el Illimani. En la búsqueda para alquilar una casa conocieron a varios colombianos sin familia, algunos migrantes forzados y otros que salieron en busca de mejores oportunidades económicas, o al menos, eso era lo que decían.

\footnotetext{
${ }^{41}$ Comunidad religiosa cristiana nacida en Londres. Actualmente se encuentra en más de 40 países.
} 
Entre los más recordados está Francisco Cortés, militante colombiano, que había estado preso en Bolivia ${ }^{42}$. En su tiempo de libertad condicional les explicaba "todo lo que era ser refugiado" y los alertaba acerca de los engaños con los que él se había topado. Se preocupaba por la educación de los niños. Helena, tercera hija de la familia, en ese momento tenía 12 años. Recuerda sus palabras: "El único consejo que les doy es que, si ven una hoja y un lápiz, hagan cualquier cosa con ellas: escribir, multiplicar, sumar. Y lean todo lo que encuentren en el camino, eso siempre les va a servir".

El hombre vivía con su nueva pareja en una habitación y recibía a todos los colombianos que solicitaban ayuda. Cuando le advertían que si seguía haciendo eso lo iban a matar, respondía: "No importa, todos somos colombianos". Un día los visitó en Tembladerani. Agachó la cabeza y dijo: "Esto me mata, cómo es posible que unos niños estén viviendo asi".

Diego agrega, "no sabíamos quién era más pobre, si Pacho o nosotros. A él le daba tristeza ver cómo vivíamos nosotros y a nosotros nos daba tristeza cómo vivía él”.

Pacho, como le decían sus amigos, volvió a estar recluido y aislado en el $2010^{43}$ en Bolivia. En octubre de 2014 apareció su cadáver en una morgue del Hospital de Clínicas de La Paz. "Siempre quedé con la esperanza de volverlo a ver", se apena Diego.

Alejandra recuerda con nostalgia ese período en Bolivia. Era la unión de unos hijos huérfanos de diferentes regiones del país y juntos formaban una familia. Los domingos comían sancocho ${ }^{44}$ y hasta celebraron con el cónsul el 20 de julio, día conmemorativo de la independencia de Colombia.

\footnotetext{
42 Organización Mundial contra la Tortura. (17 de enero de 2005). Detención arbitraria del Sr. Francisco Cortés Aguilar. Recuperado de: http://www.omct.org/es/human-rights-defenders/urgent-interventions/bolivia/2005/11/d17763/

${ }^{43}$ El Tiempo. (6 de octubre de 2014). Un colombiano, el tema de la seguridad nacional boliviana. Recuperado de: http://www.eltiempo.com/mundo/latinoamerica/francisco-cortes-aguilar-exmilitante-del-eln-en-bolivia/14649035

${ }^{44}$ Sopa caliente con papa, yuca y carne.
} 


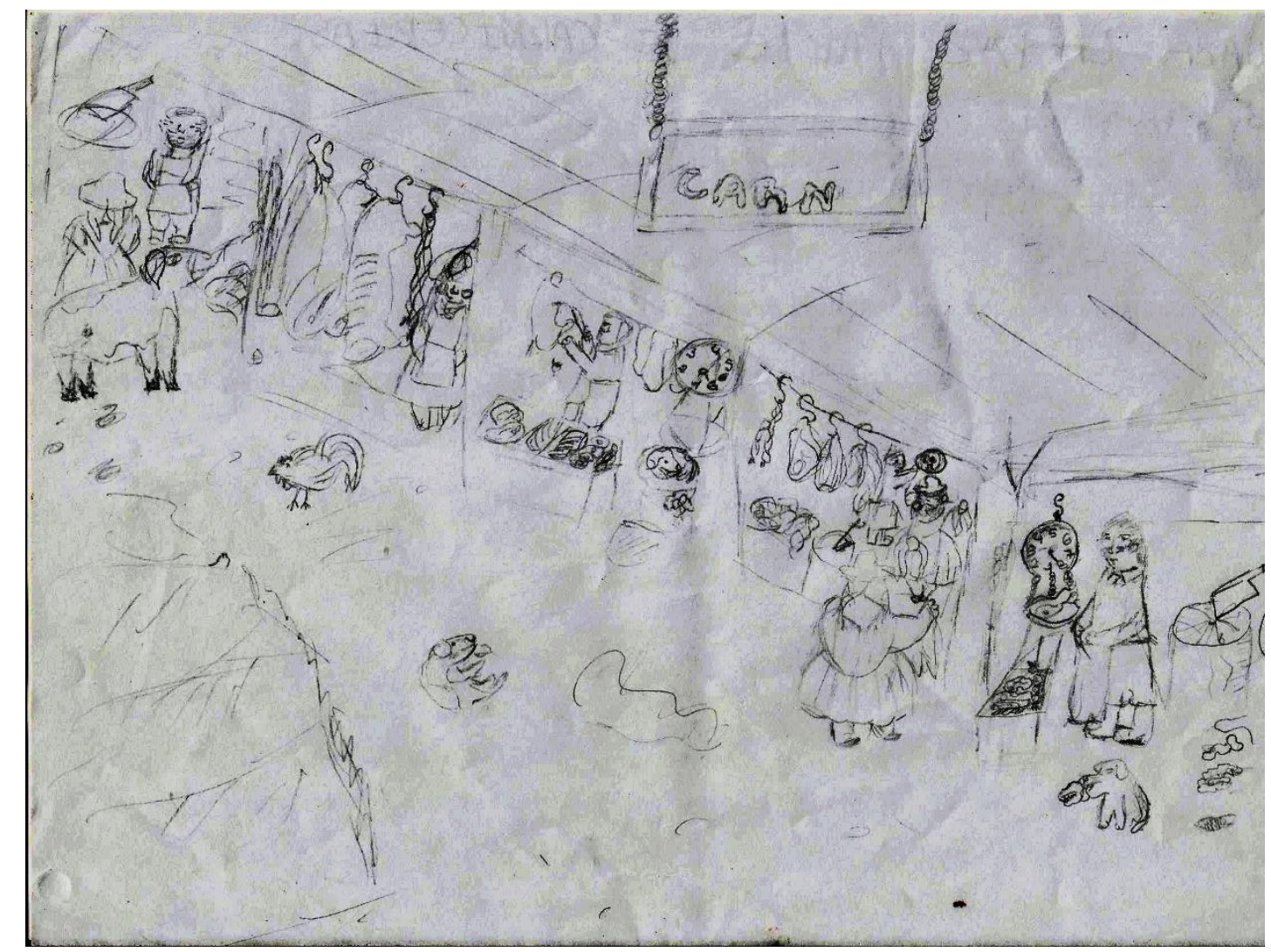

Recuerdo infantil de una carnicería en la paz. Pintado por la tercera hija de la familia, hoy adolescente.

\section{El daño social del colonialismo}

Aunque el entorno de expatriados los hacía sentir en casa, también estaba la discriminación. A tres de los niños de la familia los escupieron, no les vendían en la tienda, les decían "argentinos, venezolanos, devuélvanse a su país". Alejandra recuerda cómo era vivir fuera del circuito turístico de La Paz: "Salía y me daba miedo. Me sentía el demonio, hombres y mujeres me miraban con odio. Es feo que se fijen en vos así, ya era otro tipo de inseguridad", dice intercalando el acento argentino.

Diego vendía lámparas de bambú que él mismo diseñaba. Un día quiso ir a ofrecerlas en la plaza, como los demás artesanos de La Paz.

-No se puede poner aquí - le dijo una mujer.

-¿Cuánto hay que pagar por el lugar?

-No, no se puede, señor.

-Pero si yo no le hago competencia a ninguno, nadie vende esto. 
De repente, la mujer hurgó debajo de su falda y sacó un palo. Aparecieron otros comerciantes armados para perseguirlo. Como pudo, Diego impidió que se cayeran las artesanías y corrió lejos de la plaza. "Están organizados en gremio, y en cierta forma tenían razón, uno llegar así ahí, donde ellos trabajan”, explica.

La situación se había vuelto insostenible. No veía cómo sus hijos podrían estudiar y en qué podría emplearse. A Alejandra la policía, basada en su color de piel claro, le había advertido que su documento de refugiada no era legal. Dijeron que "ella era argentina", pidieron un soborno y recalcaron que si la volvían a ver se la llevarían presa.

ACNUR no pudo hacer mucho frente a la discriminación que sufrió la familia en Bolivia. Hablaron con Santiago Jiménez, presidente del Observatorio de Derechos Humanos de Bolivia. Debatieron con sus nuevos amigos cuál sería el mejor destino y concluyeron: Brasil.

\section{Campo Grande, Brasil: 6.375,1 Km}

El viernes 6 de octubre de 2006, la familia embarcó hacia Brasil en "el tren de la muerte", un tren destartalado con sillas de madera que parecía un tigre desnutrido al que le flaqueaban las patas con cada brida del carril. Sus ocupantes eran los desprotegidos históricos, ya parecían parte del paisaje del tren, perturbable por el bullicio de cabras, chivos y gallos.

Fueron más de veinte horas de trayecto entre la selva. Los niños iban contentos, comieron durante el viaje y celebraron el cumpleaños número siete de su hermano Jairo. Llegaron a Puerto Quijarro, frontera con Brasil. Escribieron a sus amigos de Bolivia.

El domingo querían cruzar la frontera. El miedo los impulsó a hacerlo con una estrategia: primero pasó Diego y notó que la policía no lo detuvo. Llegó al pueblo más cercano, Corumbá, y regresó en la tarde por todos. Se volvieron a dividir: Alejandra y Mercedes cruzaron la frontera con los niños, Diego y su segundo hijo, Carlos, pasaron las maletas por una trocha.

Se quedaron quince días ahí para que la vacuna de la fiebre amarilla surtiera efecto. Hablaron con el sacerdote del pueblo, el padre Genoir, y se hospedaron en la capilla Do Menino Jesús de Corumbá. Durante la misa, el religioso les habló 
a los asistentes sobre la familia Mejía, pidió que los ayudaran a aprender portugués. Ibanniños y adultos a enseñarles el idioma. Cuando se despidieron, los feligreses Iloraron. "Me impactó. Nunca había visto hombres Ilorando", recuerda Alejandra.

Uno de esos feligreses los llevó en su camioneta hasta Campo Grande, la capital del estado de Mato Grosso do Sul, a mil kilómetros de Brasilia, donde pensaron que encontrarían más atención humanitaria. El ACNUR los ubicó en el Centro de Apoio ao Migrante, CEDAMI, administrado por monjas scalabrinianas, que tenían niños para adopción. Allí sólo podían estar de noche. Era verano y el calor se tornaba irrespirable. Alejandra, la mayor, llevaba a jugar a sus hermanos a un parque cercano, todo el día, todos los días. Después de ocho años, afirma: "Ahora recién pienso: éramos niños en situación de calle".

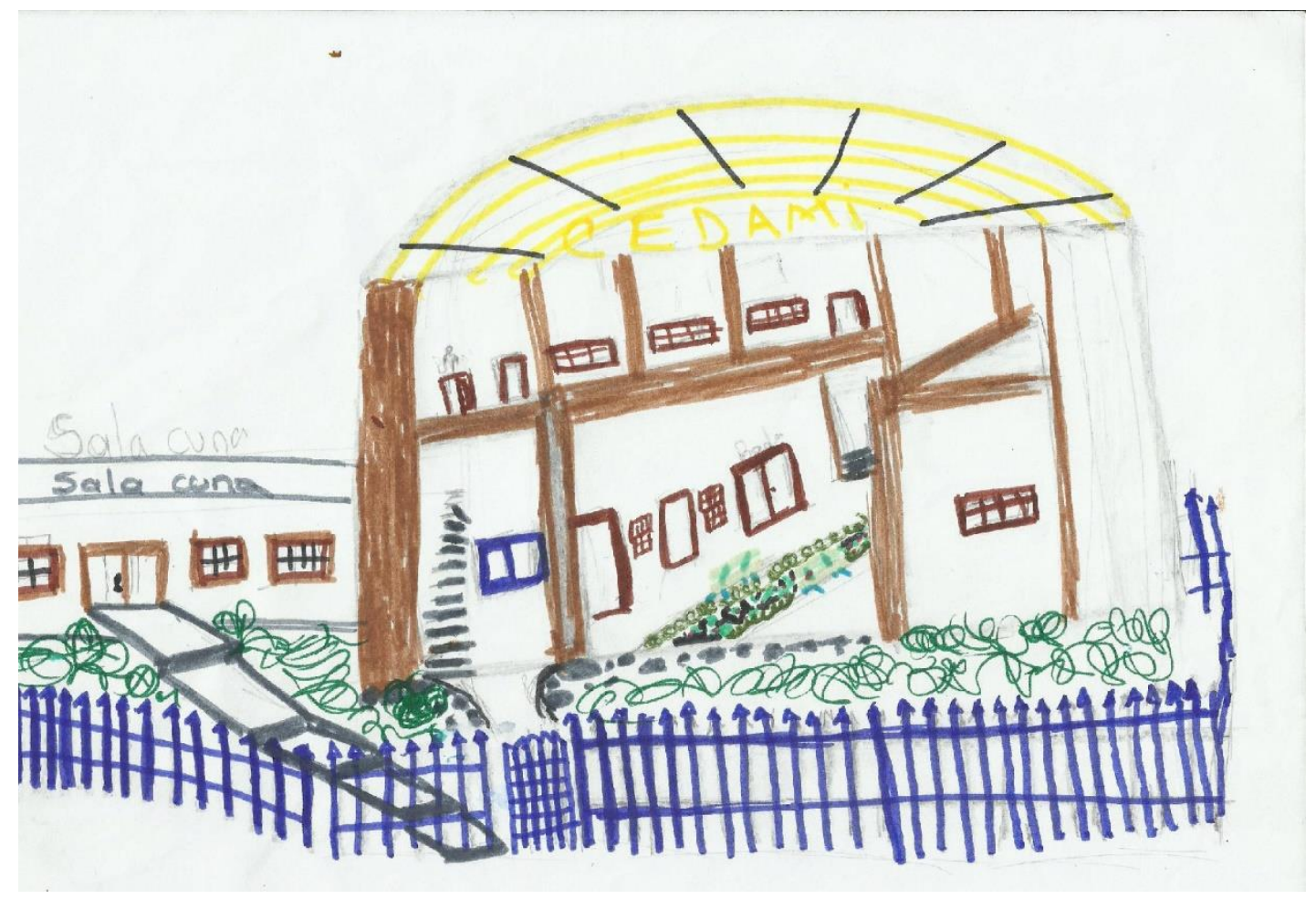

Recuerdo de la fachada del centro de refugiado en Brasil. Dibujado por Mercedes, madre de la familia.

Cuando se enteraron de que la madre superiora mandaba a las parejas adoptantes al parque para que vieran a sus hermanos, aceleraron la búsqueda de vivienda. "Todo el mundo intentando quitarle lo de uno, todo lo que me habían quitado y allá me iban a quitar los niños", recuerda con indignación Mercedes. 
En esa época supo que estaba en embarazo. No quería más hijos. Se deprime. No quiso aprender portugués, aunque hoy en día le da órdenes a las mascotas en ese idioma. Se sentía más lejos de lo que pensó que estaría de Colombia, y se avecinaba la primera Navidad fuera de su patria, la misma que había maldecido entre lágrimas cuando pasó a Ecuador.

Alquilaron un "Quitinete" en Nova Lima. El barrio tenía las calles sin pavimentar, se había conformado a finales del siglo XIX por migrantes de otros estados del país que visitaban a sus parientes con lepra en el Hospital de São Julião, insignia en el tratamiento de la endemia.

Ahí se contactaron con monjas que pertenecían a la orden "Carmelitas Descalzas", la mayoría colombianas. Alejandra llevaba días con dolor en un brazo y ellas le descubrieron una neumonía. "La traía desde Bolivia". Gracias a las recomendaciones de las monjas, los dos hijos mayores entraron a estudiar mecánica en Cidade dos Meninos. Alejandra era la única mujer y no sabía mucho portugués. El 19 de abril, Día del Indio, sus compañeros la felicitaron.

Los más pequeños sufrían menos discriminación en la escuela de São Julião. Dos meses después, su penúltimo hermano, Jairo, se cayó y se accidentó el brazo derecho. El primer centro de salud lo rechazó por no ser brasilero. Un médico japonés dio la orden para que la ambulancia lo remitiera al Hospital de Campo Grande.

Mercedes se impresionó por la noticia de la cirugía del niño. Su parto se adelantó veinte días. A Diego cada vez le era más difícil vender las artesanías en Brasil porque, en palabras de la familia, "son nacionalistas, no compran nada que no sea hecho allá" y por no tener "carteira de trabalho" no los empleaban.

Ocho meses después de haberse instalado en Brasil, les dieron los status de refugiados y la "carteira". Por ese tiempo, habitaban el barrio dos colombianos que se ufanaban de haber sido paramilitares y narcotraficantes. Las monjas decían que ellos se habían arrepentido de sus pecados. Nunca hubo un acoso directo. Alejandra dice que la situación era tensa: "Saber que por ellos habíamos salido del país y encontrarlos otra vez nos daba rabia. Nos dimos cuenta que ACNUR nos quería a todos en la misma zona". 
Omar fue uno de los migrantes forzados que conocieron en el CEDAMI. Tenía 30 años y siempre se le veía afligido. En Bogotá había sido carpintero. Un día "los muchachos del barrio" 45 habían llegado a proponerle un trabajo en la Hormiga, Putumayo, al sur de Colombia. A 20 días de estar en una finca de ese municipio, masacraron a sus compañeros. Él se salvó porque había ido a comprar a la tienda. Escapó. Desde ahí, empezó a hacer parte de la odisea compartida que vivieron los migrantes forzados en Ecuador, Bolivia y Brasil.

En Brasil, Omar conoció a una ex guerrillera embarazada y a su novio. Los tres se fueron juntos a São Paulo ${ }^{46}$. Creían que ACNUR a través de la arquidiócesis tendría mayor capacidad de atención, y de ser así la familia se iría más adelante. Se comunicaban con regularidad, pero las situaciones cada vez eran peores. Les contaban de filas extensas de migrantes, sobre todo africanos, y la prioridad para acceder al asilo que tenían "los paramilitares con plata". Nunca los atendieron. Les tocó pedir limosnas en las calles. Conocieron a más colombianos inconformes y lideraron una toma a las instalaciones.

"Todo eso fue en medio de su desespero, porque no organizaron nada, no llamaron a la prensa, sólo rompieron cosas allá", piensa Diego. Luego de esa protesta fueron perseguidos, al parecer por la Policía Federal. El último correo que recibieron era una proclama escrita de manera rápida de su posible desaparición forzada, una advertencia para que se cuidaran, y el anuncio de que se irían a Venezuela por Manaos.

Una semana después del correo, la funcionaria de ACNUR que llevaba el caso de la familia Mejía los llamó. Preguntó si sabían algo de Omar y ellos le contestaron que no. Les dio temor saber que estaban en un país grande y aun así corrían peligro. No hubo ninguna otra comunicación con Omar. No respondió los correos, tampoco llamó.

Otra vez creían estar inseguros, sin garantías. Las advertencias que les dieron sus amigos en Bolivia, que habían pasado por situaciones similares, ensordecían sus conciencias. A ellos les parecieron exageraciones: “¿Cómo no vamos a

\footnotetext{
45 Eufemismo empleado para nombrar a los paramilitares jóvenes que cumplen con tareas urbanas orientadas con frecuencia desde bloques rurales.

${ }^{46}$ Los entrevistados no recuerdan cuál fue la ciudad si São Paulo o Río de Janeiro. De los cuatro miembros consultados en este capítulo, tres creen que fue en Río, pero el padre de familia, que era el que mantenía comunicación con él, piensa que fue São Paulo.
} 
confiar en un cura, una monja, una ong, si todos están al servicio de la comunidad?" Le respondía con pesar Mercedes, segura de que sus amigos estaban aturdidos por la paranoia de la persecución.

Se prepararon para un nuevo éxodo. Planificaron cada detalle. Con un mapa en mano, analizaron la próxima ruta. Esta vez nada podía fallar, se acercaban al borde de Latinoamérica, al último país que los podría albergar.

\section{Buenos Aires, Argentina: $\mathbf{8 . 4 4 3 , 4} \mathbf{k m}$, un amparo sin status ${ }^{47}$}

Con la destreza de quien sigue una rutina de escape, el 1 de julio de 2007 empacaron y se alejaron de la casa. En una esquina, Carlos preguntó:

-Mamá, ¿y el bebé?

Hacía tres días había nacido el niño. Lo dejaron vestido encima de la cama, listo para salir. El método que siguieron fue tan similar a las últimas veces, que sólo incluyeron a sus siete hijos. Se olvidaron del recién nacido. Cuando iban en la esquina de la calle, lo recordaron. Volvieron por el bebé y retomaron el viaje.

Pasaron las fronteras entre Brasil (Ponta Porã) y Paraguay (Pedro Juan Caballero). "Parecíamos brasileros intentando hablar español", recuerda con humor Mercedes. Siguieron a Asunción y cruzaron corriendo el puente. "Fuimos hábiles", se enorgullece Diego. El puesto fronterizo de Asunción no reaccionó.

Las tareas estaban divididas con mayor precaución. Mientras que Diego se encargaba de hablar con los guardias, Carlos vigilaba y Alejandra se contactaba con la Defensoría del Pueblo en el local cercano.

-Señor, ¿me puede pasar un directorio de Buenos Aires?

-¿De qué parte: zona oeste, sur, norte, este, centro? "En ese momento me di cuenta que tenía la mente chiquita, de pueblo", recuerda Alejandra. Ella se preguntaba “¿para dónde iremos?, tiene que ser una ciudad inmensa”.

\footnotetext{
${ }^{47}$ El Comité de Elegibilidad para los Refugiados, CEPARE, nunca les otorga loa status de refugiado en Argentina. A pesar de que apelaron, la institución sostiene que deben argumentar por qué se vinieron de Brasil donde tenían refugio. Alejandra dice que aunque no tengan los status "nadie nos puede quitar la historia que vivimos".
} 
Diego les explicaba a los guardias, con todo el bagaje que había adquirido en los demás países, quiénes eran y por qué estaban ahí. Invocó la Convención de los Refugiados, pensó que todo sería más fácil.

-Pedimos protección bajo la Convención de Ginebra del 51.

-No le entiendo, señor. ¿Quiere ginebra?

-No, somos refugiados. Huimos de la guerra en Colombia.

El guardia llamó a su superior. Él tampoco sabía, pero se comunicó con alguien de la oficina de Migraciones. Por teléfono les explicaron a los gendarmes el protocolo que debían seguir. Sintieron que hubo mayor atención, "realmente un buen recibimiento"-dice Diego.

Un mes más tarde, los guardias serían testigos ante un juez del registro del bebé, cuyo cordón umbilical se cayó entre las fronteras de Brasil-Paraguay-Argentina. Diego y su familia saben que "la mejor decisión que tomamos en la vida fue salir de Brasil, si nos quedamos, Mercedes se muere, o el bebé o los dos".

Después de una entrevista, la ambulancia llevó al hospital a Mercedes, que tenía hemorragia, y al bebé prematuro. Alejandra estaba preocupada y llorosa. El médico que atendía a su madre intentó consolarla:

-"Tranquila, niña, ustedes acaban de llegar a un país peronista". 


\section{EPÍLOGO}

El fin de la guerra, el fin del exilio para los Mejía Salazar ${ }^{48}$

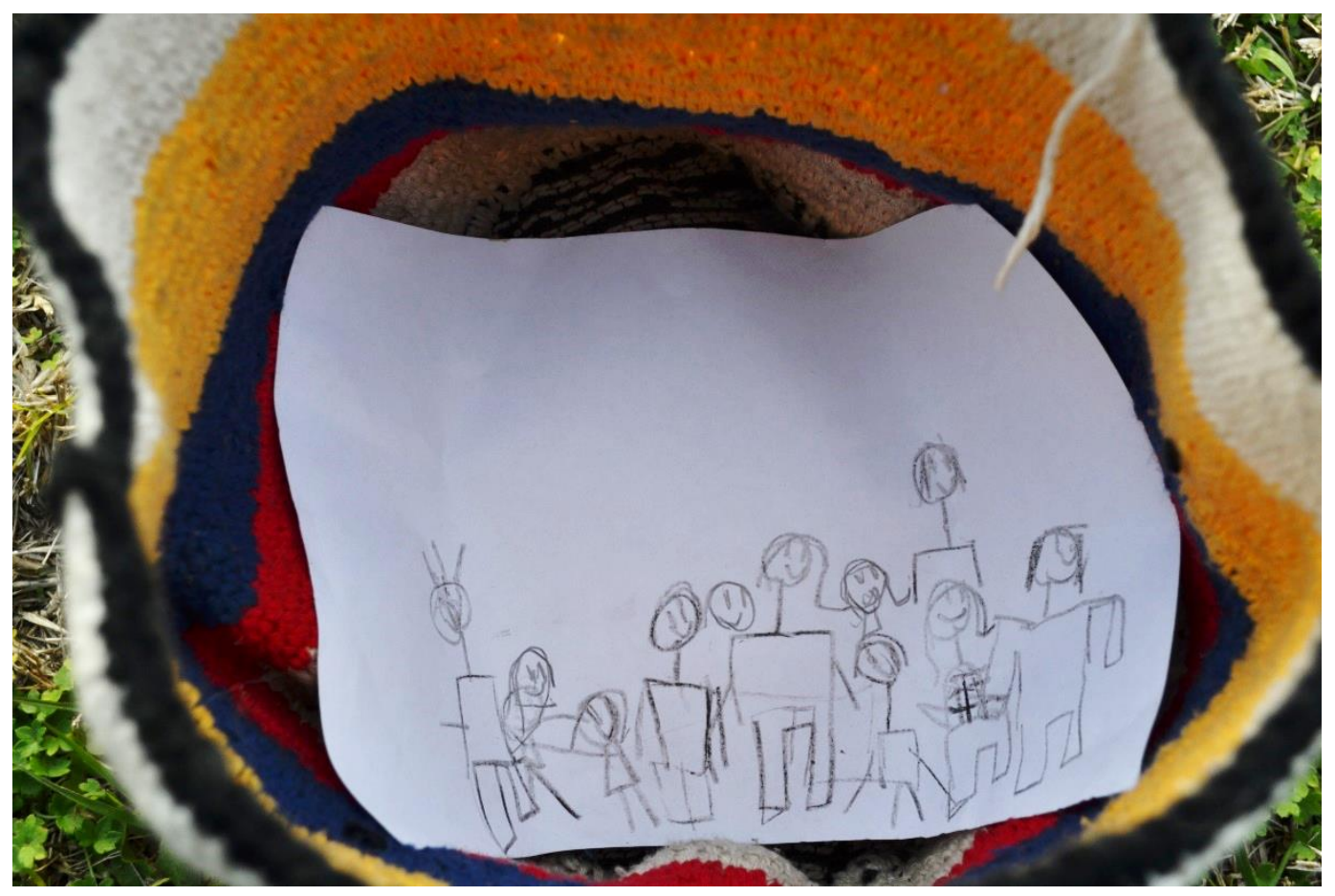

Mochila colombiana tejida por la madre de la Familia durante el trayecto forzado.

El 21 de junio de 2016, después de diez años de exilio, la familia Mejía Salazar, de origen campesino, volvió a Colombia. La pareja y cinco de sus hijos regresaron para encontrar con otros semblantes a los 150 niños que el paramilitarismo les impidió seguir alimentando en el comedor comunitario que tenían en Armenia, la ciudad de donde tuvieron que escapar para proteger sus vidas.

Quieren intentar que otros no padezcan, como ellos, una niñez desteñida entre la guerra y la orfandad. O como las de sus propios hijos, cuyas infancias fueron arrojadas a los brazos de la desigualdad y la distancia de sus orígenes.

Traen a cuestas la resistencia de la guerra colombiana en uno de sus peores períodos: 2002-2006. Sobrevivieron a tres desplazamientos violentos internos, a

\footnotetext{
${ }^{48}$ Artículo publicado en Pacifista, 13 de julio de 2016.
} 
seis viajes forzados entre países suramericanos para buscar refugio. Cruzaron todo tipo de fronteras burocráticas para exigir sus derechos.

Antes de 2006, soportaron las acciones de los principales actores del conflicto. En 2002, en zona rural del departamento del Quindío, un comandante del Ejército Nacional acusaba a los hijos mayores de ser informantes de la guerrilla. Mientras tanto, las Farc amenazaban con reclutarlos. Una paradoja propia de la psicosis de la guerra.

Huyeron a Armenia. Allí el padre, Diego Mejía, lideró acciones sociales en su barrio y se negó a recolectar votos para la reelección del expresidente Álvaro Uribe Vélez. Esa posición, asegura, lo convirtió en blanco de grupos paramilitares. Toda la familia —Mercedes, tres hijas y cuatro hijos menores de edad-presenció las amenazas y los ataques en su contra.

Diego se salvó de la muerte cuando uno de sus vecinos, el sicario que recibió la orden de asesinarlo, le dio la opción "de perderse de por aquí". El 17 de marzo de 2006, la familia partió de Colombia con la sensación de haber vivido en un Estado que parecía una "casa ajena".

Después de contactar a un amigo en Chile, planearon llegar por tierra a ese país. Sería un viaje por tierra que tardaría 20 días. A su paso por Ecuador y Perú, los interrumpió una huelga social, el robo de parte del dinero que llevaban para el viaje, la presencia de un jefe paramilitar en un albergue de Lima y la desconfianza de la policía fronteriza ante una familia con hijos pequeños de pocos rasgos en común. Nunca llegaron a Chile.

Los diez años de exilio han sido una lucha incesante por sus vidas. En países fronterizos fueron alcanzados por los tentáculos del conflicto colombiano. En medio de su travesía forzada hacia el sur del continente, los consideraron 'enemigos' de clase o de nacionalidad. Transitaron Ecuador y Paraguay, se refugiaron en Bolivia y Brasil, y residieron forzosamente en Perú y Argentina, donde vivieron los últimos nueve años.

A lo largo del recorrido, encontraron un apoyo escaso. La protección estuvo en las estrategias de supervivencia que implementaron como grupo familiar ante cada persecución y discriminación. Como cuando por parecer 'gringos' no 
pudieron vender artesanías en una plaza de La Paz, Bolivia. Tuvieron que intercambiarlas por comida para poder alimentar a los niños más pequeños.

Cansados de la distancia, se propusieron salir del exilio, aunque varias de las condiciones políticas, sociales y económicas que produjeron su destierro permanecen irresueltas. Motivada por los vientos de paz en Colombia, la pareja planeó el retorno en un vaivén entre la imaginación y la burocracia.

Volvieron con la ayuda de una organización internacional y una asociación de migrantes y exiliados colombianos con sede en Argentina. Su retorno honró la memoria de aquellos exiliados que encontraron en el camino, y murieron o desaparecieron en el anonimato de las fronteras suramericanas.

En los últimos días de exilio, los hijos menores de la familia, nacidos en Brasil y Argentina, descubrieron una parte de la patria de sus padres en el documento del consulado que "Ios volvió colombianos" — como llama Mercedes al proceso de nacionalización-. A los tres adolescentes les tocó tramitar sus identidades para salir de Argentina de forma legal. Pese al cansancio, empacaron dieciséis maletas con sus objetos personales, que son también piezas de memoria del exilio, y los documentos de todos los trámites a la que fueron sometidos por solicitantes de asilo, por refugiados, por pobres o por víctimas en el exterior. Esos papeles servirán para atestiguar la historia de esa telaraña de diligencias, esta vez por retornados.

A las 8:00 de la noche del 21 de junio de 2016 pisaron la tierra rural del centro occidente de Colombia, donde esperan vivir los próximos meses. El último tramo para llegar a la vivienda que les prestaron fue una montaña empinada y resbalosa. Con el equipaje sobre sus espaldas, subieron la pendiente. Diego Mejía no se explica con qué fuerzas: "La vida está muy cara en Argentina, las últimas semanas no comimos muy bien, sólo teníamos harina y spaghetti, y el día que llegamos a Colombia no habíamos comido".

Dos tardes después de su regreso, cuando abrían con machete un matorral para construir el camino hacia la casa, se enteraron del acuerdo sobre el cese al fuego bilateral y definitivo entre el Gobierno de Colombia y la guerrilla de las Farc. La noticia llegó en un mensaje de texto desde Argentina a un celular, el único medio electrónico que hasta ahora tienen. 
La violencia colombiana se asemeja al mar de leva, las marcas del despojo se sienten en los lugares lejanos a su origen: viajan en los cuerpos de los migrantes forzados. A los once integrantes de esta familia, dos nacidos en exilio, aún hoy los mortifica el insomnio, la arritmia cardíaca del padre, los pulmones frágiles por la neumonía, las fracturas de huesos que no se curaron a tiempo, dos hijos no terminaron sus estudios secundarios, los órganos de una madre que sufrió violencia obstétrica y los trastornos mentales causados por la guerra.

Así como las demás familias colombianas que se refugiaron del conflicto en otros países, los Mejía Salazar se fueron de su patria en la clandestinidad porque el Estado no tuvo voluntad, fuerzas ni poder para preservar su vida. La pareja regresa con el silencio de su historia, el cuerpo adulto, 50 años de edad, siete hijos retornados — dos todavía permanecen en el exterior-, y con la idea de trabajar la tierra y fundar una asociación para ayudar a los niños víctimas del conflicto.

La violencia que sufrieron en Colombia y en varios países del continente permanece en la impunidad, son diez años de exilio, de injusticia y de resistencia. Ahora están atravesados por la esperanza del nuevo futuro. Diego lo resume así: "Siento que salí de la cárcel, me siento por fin en libertad". La familia Mejía Salazar vuelve a habitar su país en un acto de paz, de coraje por la vida. 


\section{CAPÍTULO II \\ EL EXILIO COLOMBIANO, LA DISPUTA AUSENTE}

"El sujeto del exilio ha dejado de ser un sujeto histórico, porque el discurso de la historia no lo toma más en cuenta: al lanzarlo a sus bordes es borrado de toda memoria que lo recuerde. De esta manera,

al desterrado, se le deja sin voz; se le niega la oportunidad de dialogar o de intercambiar palabras con el espacio de su expulsión"

María Zambrano

A partir de los rasgos de exclusión política, social, económica y territorial narrados en la historia de vida y resistencia de la familia Mejía Salazar -Capítulo I-, este artículo propone analizar el lugar que ocupa el exilio colombiano como categoría en el contexto del conflicto armado interno. Desarrolla la idea central de la ausencia del exilio colombiano y de sus perfiles en la vida normativa y discursiva del país.

Este capítulo está compuesto por los antecedentes de la idea y praxis del exilio en Latinoamérica, en contraposición con la particularidad del caso colombiano; la descripción de las leyes que involucran a las "víctimas en el exterior", una explicación de lo que ha sido el desplazamiento forzado interno en Colombia y sus magnitudes fronterizas, para finalizar con las características de los perfiles del exilio en el entorno de la violencia social, política y económica del conflicto colombiano. 


\section{ANTECEDENTES DE EXILIO EN LATINOAMÉRICA}

Durante el siglo XX, el exilio político en Latinoamérica fue un fenómeno marcado en varios países de la región. Desde Nicaragua (1937-1979) y Guatemala (19821985), pasando por Bolivia (1974-1978 y 1980-1982), Paraguay (1954-1989), Uruguay (1973-1975) y Brasil (1964-1985) hasta llegar a Chile y Argentina con las dictaduras de los generales Augusto Pinochet (1973-1985) y Jorge Rafael Videla (1976-1983). En ese contexto de violencia y represión, cada país generó un éxodo político, con características diferentes en cada territorio, pero de grandes magnitudes, que se extendió por todo el continente.

Por ejemplo, durante la década del 70 y parte de los 80 el terrorismo de Estado en Argentina expulsó a militantes, estudiantes, obreros, intelectuales, artistas y a cualquier persona sospechosa en su proyecto de "proceso de reorganización nacional". En esa persecución no solo se vieron forzados a salir del país integrantes de movimientos sociales sino intelectuales de todas las ramas, que fueron vigilados y censurados, incluso cuando ya habían cruzado las fronteras (con las directrices del Plan Cóndor). Así, diferentes métodos represivos condicionaron las libertades de la ciudadanía provocando una escisión identitaria, cultural y política.

Durante gran parte de la mitad del siglo XX, Colombia y Venezuela vivieron procesos distintos al resto de la región. En ambos países no hubo una dictadura prolongada, el gobierno de facto del general colombiano Rojas Pinilla fue de 1953 a 1957, y el del general venezolano Marcos Pérez Jiménez de 1952 a 1958. Lo que imperó luego de sus derrocamientos fue un pacto político entre élites de los partidos tradicionales para turnarse el poder. La coalición colombiana Frente Nacional en Colombia gobernó durante 16 años el país (1958-1974). El acuerdo venezolano conocido como Pacto de Punto Fijo estuvo presente 38 años, (19581996).

Luis Roniger, sociólogo argentino y profesor de Estudios Latinoamericanos en Wake Forest University, sostiene que el exilio fue usado en Latinoamérica por los Estados-Nación como un mecanismo de exclusión y de control dentro de la 
confrontación entre las demandas de derechos sociales, políticos y económicos de la población civil y los estratos socioeconómicos establecidos desde el poder. Explica que ese entorno de carencia democrática "contribuyó a la polarización política, creando un círculo vicioso en el que el temor a la revolución provocaría represión y, a su vez, se convirtió en un factor que convenció a los grupos radicalizados a tomar la opción armada como estrategia de acción. La propia modernización de los sistemas socioeconómicos generó nuevas fuerzas en la sociedad, que el sistema político no pudo absorber a través de la institucionalización democrática”. (Roniger, 2010: 152).

El director del Centro de Investigaciones sobre América Latina y el Caribe de la Universidad Autónoma de México, Adalberto Santana, argumenta que, en el siglo XXI, el exilio político en Sudamérica no ha sido recurrente y solo corresponde a casos específicos. Esto, sostiene, debido a que los países tienen democracias más sólidas y participativas. Aunque reconoce que se han presentado episodios de exilio, luego del golpe de Estado en Venezuela (2002), Honduras (2009) y Paraguay (2012) 49 . Para el autor, la oposición de los gobiernos de Venezuela, Ecuador y Bolivia no está precisamente en el camino del exilio político sino en una migración económica, publicitada como política para desplegar "una propaganda" en contra de la democracia de esos países. (Santana, 2015: 43).

El profesor universitario Roniger centra su análisis en la evidencia de que en los últimos tiempos latinoamericanos no necesariamente se requiere de una dictadura para conducir a los ciudadanos al exilio, ni tampoco está sujeto estrictamente a integrantes de movimientos políticos. De modo que, como asegura Roniger (2010), no todas las democracias han estado dispuestas a dar asilo a la población exiliadas ni es exclusivo de los gobiernos autoritarios generar exilio.

Es en esta complejidad donde se puede ubicar un tramo del exilio colombiano, país con un sistema democrático en el que converge un conflicto armado con

\footnotetext{
${ }^{49}$ En la actualidad, se tendría que situar la atención en los acontecimientos venideros en Venezuela, Brasil y Argentina.
} 
raíces sociales, económicas y políticas por más de cinco décadas. Siendo un país democrático, ha producido distintos perfiles de exiliados sin precedentes en la historia de la región, sobre todo porque ha permeado con ímpetu la zona rural.

Colombia no fue ajena a los paradigmas de exclusión como medio para conducir la política. A partir de las últimas décadas del siglo XXI, algunos estudiosos optaron por afirmar que no existía una violencia política en el país debido a los propósitos económicos de los grupos armados ilegales implicados en el conflicto. Aunque los ideales de la mayoría de las guerrillas colombianas para la toma del poder, con alternativas distintas al sistema capitalistas, fueron manchados por la incursión del narcotráfico, la extorsión indiscriminada y acciones en contra de la integridad de civiles. No se puede realizar una escisión total entre el poder económico y político, pues ambos se encuentran interrelacionados para desarrollar o atacar un determinado modelo de sociedad, que son las directrices ideológicas enfrentadas entre las partes del conflicto. Tampoco se podría aducir de forma tajante que no existen ideologías contrarias, dadas las estructuras y las implicaciones en la vida social y política que tienen las motivaciones violentas de todos los grupos armados legales e ilegales y actores desarmados involucrados en el conflicto.

Es sabido que las partes en conflicto buscan mantener o enfrentar la hegemonía. En otras palabras: "Siendo una lucha por el control de los recursos-económicos, burocráticos, territoriales, simbólicos- necesarios para la modificación parcial o total del actual modelo de sociedad, la violencia que se libra en el país pertenecería, aún hoy, al ámbito político", (Ortiz, 2012: 138). De esa confrontación ha habido personas y familias exiliadas por causa de la violencia, pero sin ser reconocidas como tal. En la actualidad, el concepto exilio colombiano se encuentra en una incertidumbre normativa con un costo democrático elevado. 


\section{COLOMBIA, NUEVO EXILIO EN SURAMÉRICA}

El concepto exilio circunscribe a lo colectivo, a la humanidad, en una trama social que cuenta los matices de la violencia política. Esta violencia tiene implicaciones en la realización de la vida individual, familiar, comunitaria y asociativa. El exilio colombiano en el marco del conflicto armado interno genera a su vez hechos victimizantes que cercenan las participaciones propias de un Estado democrático.

Los exiliados y exiliadas fueron obligados/as a "dejar su Estado de origen como consecuencia de situaciones de violencia política generalizada o dirigidas a grupos sociales específicos, y deben buscar refugio en otro Estado durante un período cuya duración es imprevisible". (Bolzman, 2012: 4).

Si bien el exilio colombiano es casi tan antiguo como el conflicto armado, ha sido ocultado por el Estado. Durante todos los años del conflicto y en la actual época denominada "postconflicto", el término exilio no existe en el discurso oficial ni en la normativa colombiana. Desde el 2011, con la Ley 1448 de Víctimas y de Restitución de Tierras, el Estado colombiano incluye a los desterrados dentro del grupo de "víctimas en el exterior" y algunos casos se pueden cuantificar con las cifras del Alto Comisionado de las Naciones Unidas para las los Refugiados, ACNUR. Para la Convención sobre el Estatuto de los Refugiados se considera refugiada a:

"Toda persona que, debido a fundados temores de ser perseguido por motivos de raza, religión, nacionalidad, pertenencia a determinado grupo social u opiniones políticas, se encuentre fuera del país de su nacionalidad y no pueda, a causa de dichos temores, o no quiera acogerse a la protección de tal país; o que careciendo de nacionalidad y hallándose fuera del país donde antes tuviera su residencia habitual, no pueda o, a causa de dichos temores, no quiera regresar a él", (Art.1, 1951). 
Colombia tiene 350 mil nacionales refugiados o en busca de refugio (ACNUR, 2014) que abandonaron el país por causas vinculadas al conflicto armado interno o a algún tipo de persecución directa. La cifra no cuantifica el amplio número de exiliados que, por diversos motivos, prefirieren acogerse a otros estatus y no cuentan como refugiados en las bases de datos de instituciones nacionales e internacionales.

Los países de destino de los desterrados por el conflicto social, política y económico colombiano han cambiado según la época. En los años ochenta los lugares más frecuentes de exilio fueron América del Norte (Estados Unidos y Canadá) y Europa, pero las políticas anti migratorias impulsadas en los primeros ocasionaron, entre otras razones, un giro hacia países limítrofes a inicios del siglo XXI. El $81 \%$ de los colombianos y colombianas refugiados se encuentra en Suramérica. El 13\% de ellos son mayores de 60 años, el 18\% son menores de 18 años y el $33 \%$ del total son mujeres, (ACNUR, 2013). Actualmente Colombia ocupa el décimo lugar en la lista de países del mundo con mayor número de sus nacionales en condición de refugio y el primer lugar en la lista de los países del mundo con mayor población desplazada interna, (ACNUR, 2015:16-30). 


\section{EL DESCONOCIMIENTO DEL EXILIO EN COLOMBIA}

El desconocimiento acontece en un contexto de negación del fenómeno del exilio. Para algunos expertos, esta situación se debe al no reconocimiento del carácter político del conflicto, (Ortiz, Diana; Kaminke, Sergio, 2014), lo cual derivó en el ocultamiento de algunas prácticas violentas donde el Estado por acción u omisión era responsable.

En el inicio y desarrollo del conflicto, la información pública sobre prácticas violentas quedó supeditada a los intereses de los medios hegemónicos, gobiernos de turnos y comandantes de las Fuerzas Militares. En las últimas décadas en Colombia se pasó de no narrar el conflicto a contarlo a retazos. Primero bajo la mirada oficial, con declaraciones y comunicados de las Fuerzas Armadas. Luego en las audiencias de jefes desmovilizados del paramilitarismo con la Ley de Justicia y Paz, Ley 975 de 2005. Más adelante, con la Ley de Víctimas y de Restitución de Tierras, Ley 1448/2011, los grandes medios de comunicación se sumaron a esta cadena al referirse, muchas veces sin mayor profundidad, a las luchas de las víctimas del conflicto armado, desde una perspectiva cuantitativa y oficial.

A partir del 2014, medios alternativos o públicos y entidades como el Centro Nacional de Memoria Histórica $(\mathrm{CNMH})$, con el proyecto Voces del Exilio, procuraron el desarrollo de contenidos acerca de temas como refugio, migración forzada o exilio. Este material es apenas un punto de partida, pues no logra, hasta ahora, incidir en políticas de protección a los exiliados ni a reflexiones nacionales sobre el tema, pese a sus esfuerzos. Las autoridades estatales tampoco acatan las recomendaciones que realiza el $\mathrm{CNMH}$ en sus informes investigativos sobre desplazamiento interno y éxodo transfronterizo. Por diferentes razones, los resultados de sus estudios no alcanzan a ser difundidos con amplitud entre la población colombiana, audiencia exclusiva de los medios dependientes de oligopolios económicos, como Radio Cadena Nacional (RCN) y Cadena Radial Colombiana (Caracol). 
El exilio colombiano como migración forzada internacional no constituye un recorrido unidireccional ni tampoco está desprovisto de persecución, por donde transitan, residen o se refugian persiste la exclusión política, social y cultural, similar a la que los hizo abandonar sus lugares de origen. Los exiliados han sido sometidos a una ruptura cultural, económica y política profunda. En algunos casos no logran protección en el Estado receptor y han sido relegados por su propio Estado, incluso en los tiempos de la Ley de Víctimas y de Restitución de Tierras y del Acuerdo de Paz entre el Estado, a la cabeza del gobierno de Juan Manuel Santos, y del máximo jefe las Fuerzas Armadas Revolucionarias de Colombia, FARC, Rodrigo Londoño, alias Timochenko, para el fin del conflicto. 


\section{LA NORMATIVA DE "LAS VÍCTIMAS EN EL EXTERIOR”}

El presidente colombiano Juan Manuel Santos Calderón, desde el día de su posesión, 7 de agosto de 2010, manifestó que la Ley de Víctimas sería el paso principal para la reconciliación entre los colombianos. Un mes y medio después, en septiembre de 2010, sancionó personalmente el proyecto de ley ante el Congreso de la República. A pesar de las discrepancias entre congresistas y senadores alrededor de la definición del concepto y del presupuesto, la Ley se aprobó con el apoyo de la mayoría de los partidos políticos.

El 10 de junio de ese año, el presidente Santos firmó la Ley de Victimas y Restitución de Tierras, Ley 1448 de 2011, en una ceremonia en la que estuvo presente el secretario de la ONU, Ban Ki-moon. Este hecho significó para diversos sectores un avance histórico por el reconocimiento del conflicto armado interno y sus víctimas. En el discurso de ceremonia, el presidente Santos señaló que se ponía a prueba la capacidad y la voluntad tanto del Estado como de la sociedad para cumplirles a las víctimas.

La Ley tiene una vigencia de diez años a partir de la sanción presidencial y con ella surgieron organismos como la Unidad para la Atención y Reparación Integral a Víctimas, Unidad de Restitución de Tierras y el Centro Nacional de Memoria Histórica. Con la Ley por primera vez se definió a las víctimas del conflicto como "todas las personas que a partir de 1985 hayan sufrido daños como consecuencia de infracciones al Derecho Internacional Humanitario o de violaciones graves y manifiestas a las normas internacionales de Derechos Humanos, ocurridas con ocasión del conflicto armado interno". (Art. 3).

En la Ley de Víctimas no se menciona a los exiliados. Se presume que quedan en la expresión genérica "víctimas en el exterior". Ellas son nombradas solo en dos artículos de la ley para describir la difusión de información relacionada con sus derechos y designar al Sistema Nacional de Atención y Reparación a las Víctimas como órgano fundamental del Ministerio de Relaciones Exteriores para la atención de las "víctimas en el exterior", (Arts. 149 y 204).

Con esta denominación, el Estado asume que hay víctimas residiendo en el exterior, (ciudadanos/as colombianos/as y extranjeros/as), pero no desarrolla el 
término en su significado ni en las determinaciones legales. Dado los métodos de exclusión y exterminio del conflicto parte de esas "víctimas" se encuentran en el exterior de forma forzada debido a las circunstancias de violencia política, social y económica de Colombia.

Con una noción somera de lo que ha sido el desplazamiento forzado en el marco del conflicto, se percibe que el grupo "víctimas en el exterior" no está constituido en su mayoría por migrantes económicos o académicos. Cuando organizaciones han intentado indagar los motivos de su "residencia" en el exterior, se percatan que, aunque en un principio aluden causas económicas, indagando a profundidad se determina que "efectivamente su desplazamiento respondía en gran medida a situaciones de violencia y conflicto", (Servicio Jesuita Refugiados, 2006: 45).

El Estado colombiano no diseñó un ente especializado en atender y reparar a "las víctimas en el exterior", sino que delegó funciones al personal de los consulados, quienes desde siempre han cumplido con tareas diplomáticas o trámites consulares, que distan de una atención integral para víctimas. La estrategia para opacar esta falencia fue realizar, desde el 2013, "capacitaciones sobre la Ley de Víctimas" a los funcionarios de consulados y embajadas.

Con el decreto 4800 de 2011, se otorgó a las "víctimas en el exterior" la posibilidad de declarar los hechos victimizantes en embajadas y consulados del país donde estuvieran 'residiendo'. Existen datos primordiales que determinan la ruta de este grupo de víctimas. El hecho de ser refugiado no otorga por sí mismo el reconocimiento como víctima bajo los parámetros de la Ley ni los derechos a los que se puede acceder: identificación, indemnización, medidas de satisfacción y el proceso de restitución de tierras. En la práctica no se materializan en el extranjero, pues "la entrega de la mayoría de las medidas de atención y asistencia se realizará dentro de Colombia". (Unidad de Víctimas, 2013: P. 13).

Diana Ortiz, exiliada colombiana, investigadora del Instituto de Desarrollo Económico y Social, y directora del colectivo Mesa de Víctimas en Argentina con sede en la Comisión Argentina para Migrantes y Refugiados (CAREF-Buenos Aires), confirma que "Los consulados no cuentan con personal preparado para atender a las víctimas, las personas que tramitan los duplicados de las cédulas, 
hacen las entrevistas a las víctimas y el registro a las Unidades de Víctimas y de Restitución de Tierras, siendo en ocasiones sometidas a hechos revictimizantes". Además, estas instalaciones se han caracterizado por prescindir de personal, tener horarios y días laborales menos extensos, que afectan la asistencia y seguimiento a los procesos de restitución de derechos para las "víctimas en el exterior". Su carácter sigue siendo administrativo.

Las formas de acceso a la información tampoco son acordes a las condiciones en las que habitan las "víctimas en el exterior" en Suramérica. Ortiz afirma que se les dificulta el ingreso o acceso a páginas de internet: "La poca información que circula desde los consulados es virtual y toda la responsabilidad recae sobre las víctimas. Evidentemente se ha pensado en las víctimas como un conjunto más homogéneo de lo que son, un perfil de víctima más ubicada en Europa, EE. UU. o Canadá".

Asimismo, las "víctimas en el exterior" que son refugiadas, por razones intrínsecas del status no pueden acercarse a instituciones del Estado colombiano, porque algunos Estados que prestan asilo podrían considerar que su país de origen los protegerá y, por lo tanto, no requieren de la ayuda extranjera. Otro aspecto por señalar es que las víctimas que fueron perseguidas por agentes estatales o paraestatales no sienten que existan garantías para dar su testimonio, por ser el Estado 'juez y parte'. 


\subsection{ORGANIZACIONES DE "VÍCTIMAS EN EL EXTERIOR"}

En agosto de 2012 el presidente Santos Calderón confirmó los rumores de la realización de diálogos de paz entre el Gobierno y las Fuerzas Armadas Revolucionarias de Colombia, (FARC). En noviembre de ese mismo año se iniciaron los diálogos en La Habana, Cuba, para acordar seis temas: política de desarrollo agrario integral, participación política, fin del conflicto, solución de drogas ilícitas, víctimas e implementación-verificación. A partir de este anuncio, se empezaron a adherir grupos de víctimas o exiliados colombianos para diferentes propósitos y con diversas alianzas.

Con el primer borrador del punto de víctimas en los acuerdos, a finales del 2014, se creó en España la "Constituyente por la Paz de los Exiliados/as perseguidos/as por el Estado Colombiano", conformada por 40 organizaciones sociales y políticas de colombianos en el exilio ${ }^{50}$. En febrero de 2016, envió un derecho de petición a la Mesa de negociación en La Habana donde incluía como primera medida: "el Reconocimiento colectivo e individual de los exiliados/as perseguidos/as políticos/as por el Estado colombiano, como sujeto político en reclamo de sus derechos".

Otra organización que nació en el 2014 fue el "Foro Internacional de Víctimas". Desarrolla su actividad con mesas de trabajo y paneles con refugiados 0 migrantes colombianos en varios países del mundo. El Foro centra su objetivo en la visibilización de las víctimas en el exterior. En ellas incluye a la diáspora colombiana, es decir también a migrantes, "que de una u otra manera ha sido violentada". A pesar de que ha sido un interlocutor importante con instituciones nacionales, la incorporación de migrantes económicos y académicos como "víctimas en el exterior", se considera contrario a lo planteado en este trabajo.

El colectivo Mesa de Víctimas en Argentina, con influencia en el Cono Sur, desde finales de 2015 tiene como propósito "construir y fortalecer los espacios de

\footnotetext{
${ }^{50}$ Comunicado Exiliados y perseguidos por el Estado Colombiano. http://www.aipazcomun.org/wpcontent/uploads/2016/03/Intervencio\%CC\%81n-en-el-PE-de-la-CXPaz-Exiliadas_os-perseguidos_x-EC.BRUSELAS-23-feb-20162.pdf
} 
participación política de las víctimas como agentes de su propia voz, como sujetos políticos, que estén en capacidad de interlocución con los diferentes actores políticos y sociales, involucrados en las construcciones de la política pública de la memoria histórica, la verdad, la justicia la reparación y la no repetición", explica su directiva Diana Ortiz. En miras de la consolidación de los acuerdos de paz, buscan que las víctimas participen en el diseño de políticas del punto cinco de los acuerdos, concerniente a los derechos de las víctimas.

Otra organización que surgió relacionada con las "víctimas que residen en el exterior y exiliados", es la Comisión sobre Migraciones Forzadas, Exilio y Reconciliación. Nació a finales de 2015 como una iniciativa de la sociedad civil y algunos académicos. Está conformada por instituciones tradicionales de defensa de refugiados y migrantes forzados como ACNUR, SJR, Comité Permanente para la Defensa de los Derechos Humanos o la Consultoría para los Derechos Humanos y el Desplazamiento, CODHES, dos centros de estudios universitarios y del Foro Internacional de Víctimas. La Comisión hace la salvedad de no pretender representar los intereses de las víctimas del conflicto que residen en el exterior. Su trabajo se concentra en "generar acciones de incidencia dirigidas a la búsqueda de soluciones duraderas de retorno voluntario, seguro y digno, de integración local y de reasentamiento de colombianas y colombianos", expresa la integrante e investigadora Gloria Naranjo, docente de la Universidad de Antioquia.

Su incidencia es expectante en cuanto planean a futuro una Conferencia Internacional sobre Paz y Refugio para la protección de las víctimas colombianas en el exterior y la implementación de los acuerdos de Paz. 


\section{DESPLAZAMIENTO FORZADO INTERNO COLOMBIANO}

Para describir el exilio colombiano, se requiere explicar el desplazamiento forzado interno. En Colombia no existe un consenso en la fecha exacta del surgimiento del conflicto armado, lo que se puede afirmar es que durante 60 años de conflicto, la cifra que se suele calcular, han persistido las violaciones al Derecho Internacional Humanitario.

El desplazamiento forzado es una de las prácticas violentas más comunes contra la población civil en el país. Consiste en el abandono de sus lugares de orígenes ante violaciones de derechos humanos en el marco del conflicto. De acuerdo al Estatuto de Roma, este hecho constituye un delito de lesa humanidad.

En Colombia el desplazamiento forzado ocurre mediante distintas modalidades: asesinato o amenaza de muerte a uno de los integrantes del núcleo familiar, generalmente al jefe del hogar; amenaza de reclutamiento forzado, sobre todo a menores de edad; intimidaciones en la zona de procedencia por parte de una o varias organizaciones armadas por disputas por el territorio; después de perpetuadas masacres o torturas en la vía pública en las comunidades o por razones vinculadas a diversos hostigamientos entre los actores armados y la población civil.

Ante esta situación, los desplazados internos se ven obligados a trasladarse, con frecuencia, según la Procuraduría General de la Nación, a "las cabeceras municipales y las capitales departamentales". (Procuraduría General de la Nación, 2000, pág. 44). En las ciudades, las violaciones a sus derechos fundamentales continúan. La población se encuentra con múltiples dificultades que obstaculizan el proceso de adaptación a otro territorio y, en muchos casos, se les imposibilita la creación de un nuevo proyecto de vida.

El Centro Nacional de Memoria Histórica, (CNMH, 2015) denomina "desplazamiento forzado contemporáneo" al período reciente de mayor auge, que comprende desde 1980 a 2014. Y destaca como período máximo de desplazamiento forzado el desarrollado entre 1997 y 2004. Etapa que coincide 
con una legislación nacional que empieza a proteger a las víctimas de desplazamiento a partir de la Ley 387, sancionada en1997.

Con esa norma, por primera vez se crean derechos para proteger a esta población. Nace una manera de distribuir los recursos para la atención y se priorizan los lugares donde sucedieron masacres. No obstante, en esos años no hubo, por ejemplo, seguimiento de los casos de atención a población desplazada, ni un enfoque diferencial. La ley se limitó a dar a conocer los programas y asistir en problemas básicos. Pese a que existía una ley de protección a desplazados internos, esta población seguía sin garantías para ejercer sus derechos fundamentales.

En el 2004, con la sentencia S-025, la Corte Constitucional declara "un estado de cosas inconstitucionales" frente a la atención que brindan las instituciones estatales a los desplazados. Considera que existe "una vulneración sistemática a sus derechos". Desde entonces, los mandatos de la Corte Constitucional en atención a desplazados y desplazadas se han visto afectados por el desconocimiento de la norma, la voluntad política, los prejuicios de los funcionarios, la concepción de víctimas y las condiciones de acceso a restitución de derechos. 


\subsection{SURAMÉRICA, ÚLTIMO GRAN RECEPTOR DE POBLACIÓN EXILIADA COLOMBIANA}

Durante el siglo XXI, el abandono estatal convirtió a los desplazados internos en desplazados transfronterizos. Sin embargo, la migración forzada externa colombiana no cuenta con un sistema de cuantificación y tampoco una normativa para enmarcarla dentro de las prácticas de violencia. Es decir: la ley no reconoce el desplazamiento forzado externo. Debido a la ausencia en la normativa y en los estudios del fenómeno, Enán Arrieta \& Úrsula Baigorria, 2015, le propusieron al Estado ${ }^{51}$ que los derechos de las víctimas de desplazamiento forzado interno y desplazamiento externo se garantizaran de forma análoga. Hecho que fue rechazado porque la Corte Constitucional se declaró impedida para modificar la ley.

Hasta ahora, como el debate en torno al exilio no se ha dado de forma explícita en el ámbito público, en las normas e investigaciones se opta por cubrir la deficiencia terminológica y la responsabilidad estatal del hecho con el término "víctimas en el exterior".

El término "migración forzada internacional" engloba a los grupos: "refugiados" (quienes obtienen protección internacional), "solicitantes de asilo" (se encuentran en solicitud de refugio), "éxodo transfronterizo o víctimas en frontera" (prolongación del desplazamiento forzado a países vecinos con Colombia), pero no es posible incluir junto a ellos la expresión estatal colombiana: "víctimas en el exterior", pues ésta conlleva un gran vacío jurídico y político, en el contexto de un conflicto armado interno.

El sintagma destaca de las víctimas del conflicto su residencia fuera del país, más no su condición ni los motivos forzados de su migración. Se convierte, entonces, en un enunciado paradójico, en un "significante vacío", que en su amplitud termina por opacar víctimas, sus historias, sus resistencias y sus derechos.

\footnotetext{
${ }^{51}$ Con la demanda D-11139 de 2015, el abogado busca que el Estado amplíe las medidas de reconocimiento, atención, asistencia y reparación de las víctimas de desplazamiento forzado externo en la justicia transicional colombiana.
} 
Parte de esos grupos están conformados por personas que se opusieron desde su ideología y/o actividad a un modelo socioeconómico de país. Al igual que personas y familias que, aunque no hayan tenido la posibilidad de ejercer una oposición directa, padecieron acciones de abandono/despojo de sus tierras y de sus actividades, que repercutieron en la estructura social, política y económica del territorio colombiano, en cuanto fueron estratégicas para los grupos enfrentados en el conflicto. Su migración forzada es producto de una faceta de la violencia sociopolítica.

\subsection{CAMBIOS MIGRATORIOS}

En las décadas de los '70 y ' 80 , con el exterminio de la mayoría de los integrantes del partido político legal Unión Patriótica (UP) y la persecución a diferentes organizaciones de izquierdas, Angélica Pérez (2015) 52 analiza: "En ese período la gente tiene que salir a salvar sus vidas, huyendo de delitos, de ser víctima por parte de agentes del Estado". Entonces, en ese tiempo los exiliados "se asuman como tal". Los sobrevivientes del terrorismo de Estado de esos años encontraron asesoría en organizaciones de Derechos Humanos extranjeras, que conocían el contexto del país y gestionaron los trámites para las peticiones de asilo correspondientes, principalmente en países europeos.

Desde mediados y finales de los ' 90 , las dinámicas de migración forzada externa colombiana cambiaron. Un antecedente notorio es el desbordamiento del desplazamiento forzado interno: líderes, lideresas y familias campesinas cruzaron las fronteras hacia países aledaños como Venezuela, Ecuador y Panamá. Huían de amenazas contra ellos o sus comunidades, por diversos daños colaterales en los enfrentamientos entre los actores del conflicto en sus territorios. Y también a raíz de planes sistemáticos de despojo de territorios con riqueza en recursos naturales o que servían como corredores para proveer a grupos armados de municiones, alimentos, medicinas o cultivo ilícito y tráfico de estupefacientes.

\footnotetext{
52 Especial Canal Capital. (2015). Relatos del exilio, capítulo inaugural. Disponible en: https://www.youtube.com/watch?v=Um7vRyj8z_o
} 
En el período de 1997 al 2004 se presenta, como ya se dijo, un pico en el desplazamiento forzado. Con él se genera un éxodo transfronterizo. Buena parte de los desplazados internos se ven obligados a salir del país ante la crisis humanitaria en todos los municipios colombianos y el "estado de cosas inconstitucionales" generado por los organismos encargados de su atención. El Centro Nacional de Memoria Histórica de Colombia, $\mathrm{CNMH}$, investigó este fenómeno en la frontera con Venezuela. CNMH Define el éxodo transfronterizo como "una modalidad de migración forzada, que constituye una prolongación del desplazamiento forzado ocasionado en el contexto del conflicto armado y la violencia generalizada en Colombia", (CNMH, 2014: 28).

\section{3 ÉXODO FRONTERIZO}

Algunos de los exiliados colombianos están en la modalidad de éxodo transfronterizo. Juan Camilo Molina, ex investigador de ACNUR-Ecuador, confirma que entre los refugiados que llegan a Ecuador existe un "doble movimiento". "Fueron primero desplazados internos en Colombia, y después se fueron como refugiados. Hay varias razones: primero está el tema de proyección. No creo que ninguna parte del territorio colombiano sea seguro. Cuando uno va como migrante forzado a la zona periférica, donde muchas veces hay desplazamiento y violencia. Y segundo, las condiciones de vida son muy malas, el desplazamiento interno genera una situación de carencias. En Ecuador encuentran mayor seguridad y mejores condiciones de vida que en Colombia".

La conformación discursiva del enemigo también produjo el silenciamiento de prácticas violentas por parte del Estado, o de otros grupos paraestatales y sus colaboradores en las últimas décadas del conflicto. "Al crearse un solo victimario, porque a partir de los años 90 , el único victimario oficial, en un discurso que caló por los medios de comunicación, que se construyó y se fortaleció eran las FARC, concretamente. Entonces los otros agentes que provocan el exilio político como son el Estado, porque el refugiado político es el opositor, es una persona que piensa diferente que lo dice y se enfrenta, se desdibuja. Eso no quiere decir que no existan, sino que en la práctica están y en el discurso no". (Pérez, 2015). 
Esta situación les generó dificultades no sólo para ser reconocidos en el Estado colombiano o fuera de éste, sino, más grave aún, tuvo implicaciones en algunos exiliados para reconocerse a sí mismo en ese contexto. Hecho que pudo incrementar la pasividad en la defensa de los derechos de los exiliados, incluso desde la ausencia de lucha para incorporar del concepto en el ámbito nacional. "Las identidades son construidas de múltiples maneras a través de discursos, prácticas y posiciones diferentes, a menudo cruzados y antagónicos". (Hall, 1996: 17).

Semejante a la asociación que hace Scott Straus, 2006, (citado por Gómez, 2014: 5), entre la identidad y el genocidio ruandés, se puede decir que los responsables del exilio colombiano definieron la identidad de las personas que eran prestas de expulsión y, además, mantienen el poder de redefinir su identidad aún en el destierro. Los discursos inducidos, las redes transnacionales y desinformaciones alrededor de la población víctima de migración forzada externa ha sido contundente. Tanto que aún hoy en un proceso para el fin del conflicto, la incidencia social y política de esta población en el país es minúscula. (Quizás la retornada colombiana más visible a nivel nacional sea Imelda Daza, actual fórmula vicepresidencial de Rodrigo Londoño, ex jefe del Secretariado de las FARC). 


\subsection{PERFIL DEL REFUGIADO EN LA REGIÓN: COLOMBIANO CAMPESINO, INDÍGENA, AFROCOLOMBIANO}

Del 2005 hasta la fecha se manifiesta una preponderancia de una migración forzada terrestre colombiana por Suramérica. Venezuela y Ecuador fueron los países con mayor recepción de población colombiana que huía del conflicto armado. La dimensión de población fue tan masiva en dichos lugares, que en el 2004 ACNUR creó el Plan de Acción de México que incluye un programa de "reasentamiento solidario" para 'descongestionar' a países con mayor número de población refugiada colombiana.

Con esa estrategia llegaron refugiados colombianos a Chile, Argentina, Uruguay y Brasil. En el 2007, después de haberse puesto en marcha el plan, Philippe Lavanchy, director del ACNUR para las Américas, afirmó en Buenos Aires, Argentina, que "el perfil del refugiado actual en América Latina es una persona de nacionalidad colombiana y mayoritariamente campesina, indígena o afrocolombiana", (El País, 2007).

Además de esta estrategia para refugiados, los efectos del Plan Colombia y la Política de Seguridad Democrática (2002-2010) llegaron hasta las zonas de fronteras, "las cuales fueron priorizadas como zonas de alta militarización. Se impuso la idea del conflicto colombiano como una amenaza a la seguridad regional". (CNMH, 2014: 76). Una de las mayores consecuencias fue la incursión de todos los actores armados del conflicto en zonas limítrofes. Se sumó a la crisis humanitaria de asistencia, la presencia de los victimarios en estos países. Y ante esto, la población colombiana nuevamente por temor o persecución fue forzada a desplazarse a Estados más alejados del conflicto.

Otro motivo para el desplazamiento forzado colombiano hacia el sur del continente fue la estigmatización que se hizo desde Colombia de los refugiados en países fronterizos, debido a procesos que se implementaron en Venezuela con el 'Socialismo del siglo XXI' y en Ecuador con la 'Revolución Ciudadana'.

En Ecuador, luego del bombardeo al campamento de alias "Raúl Reyes", Comandante de las FARC, en la provincia de Sucumbíos, "el gobierno de Uribe 
Vélez generó mala imagen a los refugiados, los acusaba de guerrilleros. En Ecuador el tema de refugio siempre estuvo asociado a lo humanitario, a la guerra colombiana. Eran personas que necesitaban de la ayuda. A partir de ese momento se introdujo ese discurso, que ha calado hasta hoy, de dudar del refugiado, que si muchos eran guerrilleros o si están mintiendo para quedarse en el país. Por fortuna, Cancillería de Ecuador no dio paso a la política de Colombia, sino que abrió su propia política y se acogió a la Declaración de Cartagena" ${ }^{33}$, explica Juan Camilo Molina, ex funcionario de ACNUR-Ecuador.

En la última década, los exiliados colombianos se trasladaron al sur del continente para buscar protección, o al menos distancia de los tentáculos del conflicto colombiano en países vecinos. Esa presión migratoria hacia el sur ocasionó nuevos problemas. Para la investigadora Diana Ortiz, se tradujeron en "dificultades para la regularización, que reproducen los patrones del desplazamiento forzado interno en Colombia con un agravante más la estigmatización de ser 'extranjero colombiano'". Escenario que repercutió de forma negativa en la integración social de los exiliados con sus nuevos entornos receptores y en la relación de la "colonia" colombiana víctima del conflicto ${ }^{54}$.

\footnotetext{
${ }^{53}$ Con el Convenio de Cartagena, 1984, se amplió la protección a los refugiados a nivel latinoamericano, al incluir bajo esta condición a "las personas que han huido de sus países porque su vida, seguridad o libertad han sido amenazadas por la violencia generalizada, la agresión extranjera, los conflictos internos, la violación masiva de los derechos humanos u otras circunstancias que hayan perturbado gravemente el orden público".

${ }^{54}$ Un hecho reciente del cual no se hablará a profundidad este ensayo, pero es necesario nombrar para dar cuenta de las dinámicas de la migración colombiana, es el retorno masivo de colombianos, sus descendientes y demás familiares, quienes en décadas pasadas huyeron a Venezuela por razones asociadas al conflicto.
} 


\section{PERFILES DE EXILIADOS COLOMBIANOS ENTRE LO AUTÉNTICO Y LO OCULTO}

Aunque la complejidad y prolongación del conflicto colombiano produzca confusión en delimitar ciertas categorías, en el caso del concepto "exilio colombiano" es necesario establecer ciertas aproximaciones a este fenómeno en cuanto que su reconocimiento es un aporte justo a la democracia y a la memoria histórica del país.

En los años del conflicto y en todas las categorías fragmentadas de la migración forzada colombiana, existen diversos individuos y grupos, excluidos políticos y sociales, que son exiliados y tienen en común el destierro como única salida de sobrevivencia a la violencia, la exclusión permanente de sus derechos y el retorno impreciso o inestable. No podrán regresar de forma permanente y segura "hasta que las condiciones políticas que dieron lugar a la partida dejen de existir". (Bolzman, 2012: 10). Este último aspecto no se subsanará con el acuerdo de paz ya que su implementación y verificación son un proceso paulatino, no un hecho inmediato que modifica las causas y secuelas del conflicto.

Para algunos expertos en el tema, desde el 2005 el perfil del exiliado en Suramérica corresponde principalmente a los opositores de la política de Seguridad Democrática del ex presidente Álvaro Uribe Vélez, 2002-2010. Entonces, en esa etapa "los principales blancos de la represión fueron los defensores de derechos humanos, académicos y líderes sociales". (Ortiz; Kaminke, 2014: 42). 


\subsection{EXILIO EN DEMOCRACIA}

En un principio, la migración forzada externa se determina como un hecho individual. Sin embargo, al hacer un seguimiento en los casos, se puede determinar que el desplazamiento se produce en general por grupo familiar. El investigador Juan Camilo Molina, reflexiona sobre los refugiados colombianos en Ecuador: "Es cierto que la primera persona que sale del país es el hombre, pero de seis meses a un año se reencuentra en el exterior con el resto de su familia. Entonces, no son individuos solos, la mayoría son familias. Pero no hay un dato cierto de la composición de la familia, no hay censo general". Ocurre algo similar para los que buscaron protección en Europa. Se presenta un desplazamiento familiar debido a que las amenazas fueron directamente a la familia o incluso, luego de que la familia nuclear se traslada, llegan nuevas persecuciones a otros parientes.

En Colombia se ha presentado una represión violenta desde el Estado y su maquinaria paraestatal dirigida a perseguir a la izquierda, legal e ilegal. En el camino de la "lucha contra el enemigo" es oportuno observar cómo la constitución del conflicto y los discursos oficiales que se enhebraron produjeron la legitimación de un ataque armado indiscriminado: hubo sospechosos de subversivos, fuego cruzado, ejecuciones extra judiciales y montajes judiciales en un intercambio de información entre los organismos de inteligencia y los grupos paramilitares. De ese modo, en la persecución se abatió a los partidarios de la izquierda, a los sospechosos de serlo, a las familias de ambos y a la población desprotegida por el Estado.

La población que más ha sentido los estragos del conflicto colombiano se encuentra en zonas rurales, donde ocurre un "gota a gota" como reflexiona la investigadora Martha Nubia Bello, investigadora del Centro Nacional de Memoria Histórica, CNMH: "El conflicto acontece en los lugares más apartados, en las márgenes, en los corregimientos, en las veredas ${ }^{55}$ y esa acumulación de muertes de pequeños grupos de muertes, de asesinatos selectivos, uno a uno, gota a gota, en las márgenes en las fronteras, hace que se acumulen los datos, que

\footnotetext{
${ }^{55}$ Vereda en Colombia es una zona rural, que es una subdivisión del municipio (ubicarlo con más precisión).
} 
sumen, sumen, pero que no aparezcan como un hecho contundente, espectacular como sí ha ocurrido en diferentes contextos latinoamericanos". (CNMH, 2014). Con ese mismo método se han perpetuado diversas prácticas violentas del conflicto, como por ejemplo las ejecuciones extrajudiciales ("falsos positivos"), cuando han ocurrido de forma masiva no ha sido posible documentarlos con todos los enfoques respectivos y oportunos.

Además de que es exacerbado en las zonas rurales, se debe tener en cuenta para definir los perfiles del exilio que a los actores armados del conflicto contemporáneo (las Fuerzas Armadas colombianas, las guerrillas: Ejército de Liberación Nacional, ELN, y Fuerzas Armadas Revolucionarias de Colombia, FARC, y grupos paramilitares), desde el siglo $X X$, se les suman otro tipo de actores: las multinacionales que explotan recursos naturales y "que tienen connotaciones políticas asociadas con modelos económicos" 56 . También aquellas instituciones estatales que apoyaron a los paramilitares para cometer acciones criminales en contra de la población civil. $Y$ en ese marco se presentan partes "no armadas" en el conflicto como alcaldes, congresistas, concejales, ministros y gobernadores pero que respaldaron con financiamiento y logística el despliegue de estos grupos en todo el país, aún luego de la 'desmovilización' de las Autodefensas Unidas de Colombia (AUC) en el 2006.

Algunos de los implicados en estas alianzas criminales o en actos de corrupción para favorecer la clase política dominante, salieron del país y se autodenominaron "perseguidos políticos". Un tipo de "exilio" que, según el Centro Democrático, liderado por el ex presidente Uribe, tiene que ver con una "persecución política por vía judicial". Es el caso del ex ministro de agricultura, Andrés Felipe Arias $^{57}$, o el ex comisionado de paz, Luis Carlos Restrepo, prófugos de la justicia. Este tipo de manifestaciones confunden y desdibujan aún más la categoría exilio en el marco del conflicto colombiano y también son replicadas en ese contexto por medios masivos de comunicación.

\footnotetext{
${ }^{56}$ Marco Velásquez. La violencia política en Colombia: situación y perspectivas 25 de noviembre de 2013. Razón pública. http://razonpublica.com/index.php/politica-y-gobiernotemas-27/7211-la-violencia-pol\%C3\%ADtica-en-colombia-situaci\%C3\%B3n-y-perspectivas.html ${ }^{57}$ Ex ministro de agricultura del segundo período de gobierno de Uribe Vélez. Luego de un año de petición de asilo en EE. UU por "persecución política" fue extraditado a Colombia por orden de la Corte Suprema de Justicia.
} 
En la actualidad continúa la presencia paramilitar en Colombia, pues no todos sus integrantes entregaron las armas con la Ley de Justicia y Paz, Ley 975 de 2005. Y en algunos casos hubo una reconfiguración con integrantes que luego de "desmovilizarse" volvieron a delinquir. El Estado colombiano no acepta el carácter paramilitar de estos grupos. Los llama "Bandas Criminales, BACRIM", o "combos al servicio del narcotráfico", aun cuando desarrollan las mismas estrategias, controlan territorios donde ejercían poder las AUC -como queda demostrado en sus acciones- ${ }^{58}$, se oponen con violencia a las actividades de los líderes, a la restitución de tierras para los retornados (desplazados internos que regresan a su territorio de origen) y han estado involucrados en atentados y asesinatos a defensores de derechos humanos en el país.

Con estos actores las dinámicas del conflicto se tornan complejas. No son dos o tres partes armadas enfrentadas, Estado y grupos disidentes, sino que existe un conglomerado de disputas donde confluyen actores armados y no armados. "Colombia vive desde hace más de medio siglo una situación de violencia generalizada en la que se entrecruzan motivaciones políticas, económicas y sociales y donde el uso intencional y desmedido de la fuerza ha devenido un rasgo predominante de las relaciones sociales" (Ortiz, 2012: P.4). Este entrecruzamiento ocasiona, en términos weberianos, que no haya un solo poder que atesore la violencia.

\footnotetext{
58 (parte de su control se evidenció en el "paro armado" en los departamentos de Antioquia, Chocó y Córdoba). Semana. 31 de marzo de 2016. Paro armado y la otra estrategia del Clan Úsuga. http://www.semana.com/nacion/articulo/clan-usuga-planea-paro-armado-en-antioquia-ycordoba/467463
} 


\subsection{EXILIADOSIAS: SOBREVIVIENTES DEL EXTERMINIO}

En esa trama de violencia y con diversos actores se ha exterminado muchas de las organizaciones sociales en cualquier ámbito territorial, así como a sectores campesinos. Su lucha o presencia entorpecía los planes de un determinado modelo social. El país y sus zonas rurales tuvieron un recrudecimiento de violencia política, aquella "ejercida como medio de lucha político-social, ya sea con el fin de mantener, modificar, sustituir o destruir un modelo de Estado o de sociedad, o también para destruir o reprimir a un grupo humano con identidad dentro de la sociedad por su afinidad social, política, gremial, étnica, racial, religiosa, cultural o ideológica, esté o no organizado”, (CINEP, 2009: 6).

La definición explica, además, que la violencia política en Colombia ha sido ejercida por agentes del Estado o por particulares que actúan con apoyo, tolerancia o aquiescencia de las autoridades del Estado. $Y$ son violaciones a los derechos humanos, por grupos insurgentes que combaten contra el Estado y se dan como acciones bélicas o infracciones al Derecho Internacional Humanitario o por grupos o personas ajenas al Estado y a la insurgencia, pero impulsados por motivaciones ideológico- políticas.

En esa medida, una definición aproximada a lo que sería el exiliado colombiano, al que no se le ha hecho ningún reconocimiento jurídico, simbólico y reparatorio, correspondería a una persona que ha debido huir del país en el marco del conflicto para evadir su exterminio físico por su afinidad social, política, gremial, étnica, racial, religiosa, cultural o ideológica esté o no organizado ${ }^{59}$. Es importante señalar, tal y como lo expresa la definición del CINEP, que no necesariamente el exiliado colombiano, víctima de violencia política, tuvo que huir por su afiliación a una organización o por un asunto directamente político, sino que predomina un cruce multicausal, donde la política y los laberintos sociales de un país con un conflicto prolongado ocupan un lugar importante.

\footnotetext{
${ }^{59}$ Cabe aclarar que con esto no se pretende hacer una jerarquización entre las 'víctimas en el exterior' sino identificar que dentro de ese grupo de víctimas existen los exiliados colombianos y su migración forzada responde directamente a razones políticas en el marco de un conflicto socio-político y económico armado
} 
Por el carácter rural que ha tenido el conflicto, la resistencia que ha habido no se limita sólo a lo corporativo o asociativo, sino que tiene un rango más amplio. Abarca individuos y familias. Estas personas, hayan o no desarrollado un papel de liderazgo cívico en sus territorios, se convirtieron en un obstáculo para ejecutar los planes y proyectos de los grupos armados y no armados del conflicto. En esa medida, en el caso colombiano, su desplazamiento forzado internacional también se circunscribe dentro de la categoría exilio, pues su destierro fue funcional para imponer con violencia un control económico, social y político ${ }^{60}$.

En ese contexto el exilio, aunque también se da de ese modo, no es propiamente un hecho vinculado exclusivamente a partidos políticos sino también a movimientos afiliados o fragmentados y de personas, en su mayoría campesinos, que huyeron del país debido a la ejecución de los objetivos de los grupos armados directos y no armados, legales e ilegales, del conflicto en sus territorios.

Con esto, se plantea el hecho de que la categoría exilio no la conforman víctimas que quedaron "en medio del fuego cruzado" o que huyeron porque en sus zonas de origen había "un estado generalizado de violencia", sino que son personas que fueron forzadas a dejar sus territorios, su actividad económica y su contribución política en Colombia porque estorbaban en los planes de la guerra y su lejanía permitía a los grupos armados incrementar su poderío. También se expresa una marcada diferencia con el perfil del exiliado 'habitual', más cercano a partidos o al área intelectual de un país. En el caso colombiano, pese a que no esté reconocido, es una figura de oposición directa e indirecta que resistió a todas las caras de violencia socio-política en el marco de un conflicto armado interno.

\footnotetext{
${ }^{60}$ No se incluye a los colombianos/as que salieron del país en busca de mejores oportunidades laborales o profesionales.
} 
Entonces, en la categoría exilio colombiano se aglomeran integrantes de movimientos políticos, principalmente de izquierda, partidos alternativos, una clase intelectual-periodistas, escritores y artistas- que fueron amenazados por contar a través de su profesión o militancia la violencia colombiana. Pero sobre todo incluye a una población mucho más vulnerable en cuanto a derechos humanos: los campesinos, líderes, lideresas que lucharon, agrupados o no, por los derechos de su barrio, sus municipios, la protección de sus comunidades, sectores o gremios e individuos anónimos que aun cuando no tuvieran un vínculo partidista o formación ideológica explícita fueron obligados a dejar sus labores, propiedad y territorios en un acto de violencia socio-política. Así se encuentra que el exilio colombiano tiene unas particularidades a las que no se le ha hecho el respectivo estudio académico ni el reconocimiento jurídico. Hasta ahora, tampoco, cuenta con una lucha que lo reivindique colectivamente.

En los tiempos actuales, la identidad definida para perseguir, desplazar y minimizar los hechos violentos se mantiene en cuanto el Estado colombiano desconoce que durante los años de conflicto hubo exiliados/as y familias enteras exiliadas por causa de la violencia política, social y económica. A cambio, mantiene la concepción identitaria de la "víctima" del conflicto que "reside" en el exterior.

De esa concepción se desprende la ausencia de una reparación justa y de la búsqueda de la verdad de los hechos que produjeron el exilio, tanto para los que deciden retornar como para los que siguen residiendo en el exterior. Mientras el Estado colombiano no reconozca el exilio como hecho víctimizante en el marco de una migración forzada internacional, para ambos grupos, el peso de los estereotipos creados para desterrarlos se conservará, al igual que la "amenaza perpetua del extermino", (Kaufman, 2011) y la impunidad. 


\section{CAPÍTULO III \\ MEMORIAS DEL EXILIO Y EL RETORNO}

"Todos queremos pescar la memoria como pescadores, pero los peces no son la memoria, la memoria es el río y nosotros somos parte de ese río".

Horst

Hoheisel

A continuación, aparecen los fragmentos de los discursos que se enunciaron en las exposiciones con los objetos de memoria de la familia Mejía Salazar en La Plata, Argentina (2015) ${ }^{61}$ y en Bogotá, Colombia (2016) ${ }^{62}$. La primera, cuando la familia aún se encontraba en exilio y la segunda, a los cuatro meses de haber retornado a Colombia.

\subsection{SUMARIO DEL TRAYECTO}

La muestra 'Casa Ajena' narró con objetos de memoria la historia de vida y resistencia de una familia colombiana exiliada, conformada por la pareja y sus nueve hijos, dos de ellos nacidos en el exilio. La familia Mejía Salazar huyó de Colombia en el 2006 debido a los distintos hostigamientos por parte de los principales actores involucrados en el Conflicto Armado.

En el 2002, cuando vivían en zona rural del Quindío, las FARC pidieron el reclutamiento de la hija e hijo mayor de la familia, que para esa época tenían 14 y 13 años de edad. Los padres evitaron este reclutamiento, pero unas semanas

\footnotetext{
${ }^{61}$ Centro Nacional de Memoria Histórica. (2015) Casa Ajena: https://www.youtube.com/watch?v=cx7NtMVxaNY

${ }^{62}$ Centro Nacional de Memoria Histórica. (2017) Casa ajena: Memorias de exilio y retorno.

https://www.youtube.com/watch?v=4CZMZsMvCY8\&t=20s
} 
después, el Ejército Nacional los acusó de ser informantes de la guerrilla. Con esta situación fueron víctimas de desplazamiento forzado interno y llegaron a la ciudad de Armenia. Allí desde el 2005, los paramilitares amenazaron de forma reiterada al padre de esta familia por sus labores como líder comunitario.

Cuando le pregunté a Diego Mejía, padre de la familia exiliada, por las circunstancias de la última amenaza de muerte, me cuenta que ese momento fue traumático. Por todas las persecuciones que ya había tenido, sintió que la huida la planeó como cuando se vive en una casa ajena y se sabe que, tarde o temprano, uno se tiene que ir. Esa frase me impresionó porque resumía la manera como sintieron al Estado colombiano en esos instantes. Decidí nombrar la muestra "Casa Ajena" porque estoy segura de que es una de las sensaciones que vivieron la mayoría de los exiliados y exiliadas al salir del país.

Pienso que, en medio de toda la violencia política y la exclusión social, los lazos de esta familia se fortalecieron. Y esto les permitió sobrevivir a los diez años de exilio. Teniendo presente esta idea, me propuse representar la resistencia de este grupo a través de sus propios objetos, tanto los que procedían de Colombia como los que adquirieron en el exilio. En la segunda muestra realizada en Colombia en el 2016, los objetos recobraron otro valor: el valor de haber sobrevivido también al retorno.

\subsection{CASA AJENA (EXILIO, 2015- RETORNO, 2016)}

En un principio, pensé sólo en contar la historia de la familia en una crónica y analizar la expansión del conflicto armado por Latinoamérica en un ensayo. La muestra, en cambio, surgió en la etapa final de la investigación, casi al año y medio de la reportería, incluso cuando ya había escrito su historia. Sabía que tenían documentos que "certificaban" todo este recorrido forzado, y creía que eran eso, solo documentos.

El día que me los mostraron, trajeron a la mesa de comedor de la casa donde habitaban en Argentina dos maletas. Contenían documentos de toda esa burocracia a la que son sometidos los solicitantes de refugio, pero además ciertos objetos que relataban el exilio: diarios del viaje forzado, 13 en total. En algunos cuadernos la parte de atrás sirvió para sacar cuentas, sobre todo restas, y a veces, supongo que era tal la necesidad de escribir que había oraciones por 
fuera de los márgenes. Banderitas empolvadas de Brasil, exámenes médicos, una biblia deteriorada que sirvió de alivio para los momentos críticos. Hebras de cabello envueltas en una hoja con un mensaje que advertía que era el primer corte de una de las niñas de la pareja, que para ese entonces tenía seis años de edad, a la que por cierto ya le cambió el tono del cabello.

También había artesanías colombianas: réplicas de jeeps, hechas por ellos, alusivas a su lugar de origen rural; una enciclopedia colombiana, que el padre empacó para que sus hijos no olvidaran cómo era su país; una agenda telefónica que alguna vez fue de color verde y hoy es rosada, en un principio, tenía los números de sus familiares en Colombia. En el avance de la migración, en sus páginas se escribieron los contactos de otros exiliados y funcionarios de organizaciones de derechos humanos.

Esos objetos no solo contaban con sus formas, colores, palabras o texturas lo que había sido el exilio, sino que los integrantes de la familia al verlos empezaron a rememorar partes de su peregrinación. Los objetos hicieron que recordaran hechos que no me habían contado antes, que ellos creían que habían olvidado o por el contrario les traían recuerdos que no alcancé a percibir, pero los comprendí a la perfección como una muñeca pequeña que para una de las hijas de la familia conserva el olor de su abuela materna.

Para mi este objeto es uno de los más emotivos porque habla de la niñez y también de la otra familia, la que espera o se resigna en Colombia. La dueña de esta muñeca, que tenía 11 años cuando se fue del país, me contó que, en Armenia, Colombia, siempre dejaba esa muñeca en la casa de su abuela materna y no se la llevaba para su casa porque sabía que iba a regresar. 


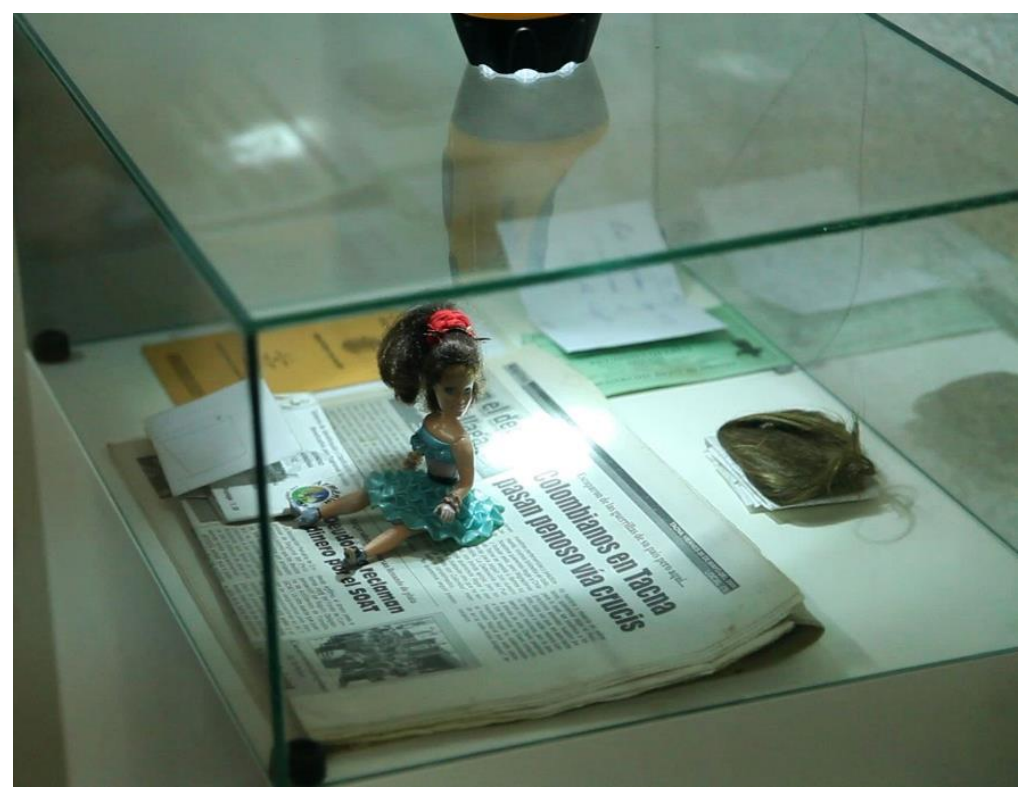

La muñeca entre otros objetos de memoria. La Plata, Argentina. 2015.

El día que su papá le dijo que se irían de Colombia, ella igual dejó su muñeca en la casa de su abuela, encima del televisor, sitio donde siempre la ponía. Con los años, su abuela al ver que sus parientes no regresaban, le envió la muñeca con otros documentos en una encomienda. Ella me dice que cuando la recibió se enojó un poco porque sentía que la abuela había perdido la esperanza de volverla a ver, no entendía por qué lo había hecho, aunque después, con una expresión infantil, me aclaró que de todas formas se alegró de tener de nuevo a su muñeca. Esa muñeca también retornó al país.

Otro objeto familiar que habla de la migración forzada constante son las pinturas enrolladas, que nunca han sido colgadas en ninguna pared, porque la familia espera estar en un lugar estable y propio para enmarcarlas. Entre los objetos también encontré archivos de prensa, donde se puede analizar la manera en la que los medios informaron sobre el exilio de esta familia. A pesar de que no contextualizaban los motivos de la migración, al menos las publicaciones de estas notas sirvieron para generar solidaridad y ayuda a la familia.

Aunque no puedo definir con exactitud qué es la memoria, el día que tuve enfrente esas dos maletas, supe que los testimonios que estaban surgiendo, mis preguntas y la presencia de los objetos, era un diálogo con la memoria del exilio. No como un hecho particular sino como una trama colectiva, representada en las voces de un grupo familiar. 
Luego de esta reflexión, los puse a la tarea de buscar más objetos. Aparecieron otros artículos entre esos, juguetes, abrigos que ya no usaban, pero guardaban por el valor afectivo que tenían. Ropa de Colombia, que utilizaron durante la migración forzada transfronteriza, uniformes escolares en países de refugio y hasta un machete, símbolo de los campesinos colombianos, estuvo con ellos en todo el trayecto forzado y se usó para abrir camino, recoger frutos y cortar la madera para las artesanías que elaboraron.

Las artesanías, sin duda, hacen parte de las estrategias de supervivencia: fueron vendidas o intercambiadas por comida para poder alimentar a los niños y niñas más pequeños de la familia, se usaron como utensilios personales. El proceso del tejido y el trabajo en madera fue una actividad en la que participaban casi todos los integrantes y esto ayudó a ocupar las horas de angustia durante el exilio. Fue como una terapia, que aún practican en el retorno.

A lo largo de tres meses, la familia, un curador argentino y yo seleccionamos con criterios de respeto y de protección a la identidad algunos de los objetos que estarían en la instalación. La muestra en Argentina se desarrolló del 2 al 9 de octubre del año 2015 en la Facultad de Periodismo y Comunicación Social, sede Miguel Bru, de la Universidad Nacional de La Plata. Tuvo como propósito visibilizar la resistencia de los exiliados colombianos, denunciar su exclusión y ser una pequeña reparación simbólica en la que se escuchara su voz y las marcas de memoria que llevaban sus objetos.

Los integrantes de la familia escribieron sobre cada uno de los objetos, (menos la hija menor que todavía no sabe escribir, pero sí dibujar y fue la encargada de pintar). Ese testimonio, al ser de una familia diversa, estuvo atravesado por la percepción de ser niño, niña, joven, mujer y hombre en el exilio. Además, este relato incluye el recuerdo de aquellos conocidos, víctimas de migración forzada que quedaron en los países por donde ellos pasaron, algunos hoy están desaparecidos o murieron en el absoluto anonimato del exilio.

Viéndolo en retrospectiva pienso que la muestra también fue un acto comunicativo, estético y a la vez político. En un pasillo universitario de postgrado, lugar de paso y por el que muchas veces se transita desprevenido, los objetos 
interpelaron a los transeúntes con un relato colectivo de resistencia. Hubo una ayuda estética con lámparas con cambio de luces, que era una señal en el camino para literalmente hacer visibles a los exiliados a través de sus pertenencias.

La segunda muestra se realizó del 30 de noviembre al 2 de diciembre de 2016 en Bogotá, Colombia, en el marco del taller "Memorias Exilio, Retorno y Éxodo Transfronerizo" del Centro Nacional de Memoria Histórica, CNMH. Allí por primera vez nombré en público los apellidos reales de la familia. Ese acto fue una pequeña contribución para que el exilio colombiano saliera del anonimato. Luego de diez fuera del país, sus nombres, cuerpos y objetos estaban de nuevo en Colombia, dispuestos a narrar su historia de resistencia y retorno.

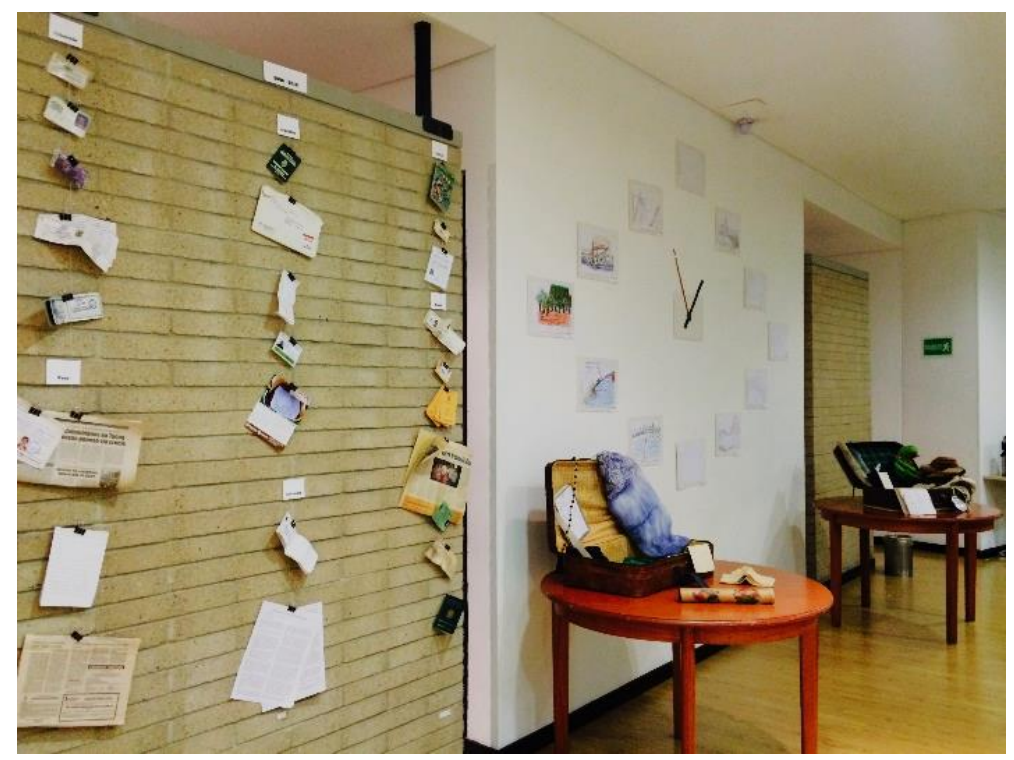

Objetos de memoria de la Familia. Bogotá, Colombia. 2016. 


\subsection{REFLEXIÓN FINAL}

Después de esta experiencia, creo que la representación de la memoria del exilio debe basarse más en el testimonio porque en los contextos de violencia, como los de Colombia, el testimonio de los sobrevivientes se silencia. A nosotros como sociedad nos falta escuchar mucho más los testimonios de las víctimas, que no son otra cosa que la lucha de sus trayectorias.

Aprendí con esta familia de exiliados -y ahora retornados- que el testimonio se puede construir con sus voces, sus textos, pero además con dibujos propios que trazan vivencias que a veces las palabras no alcanzan a describir, como la mirada de la niñez en un país de refugio como Bolivia o las condiciones de un embarazo en un centro para refugiados en Brasil.

El testimonio también está presente en sus objetos personales, sus diarios, sus prendas, las herramientas de su oficio, los papeles que los posicionaban o no en un status de refugio. Creo que el conjunto de todos estos elementos puede ayudar a transformar una casa ajena en una propia. Una casa a la que se piensa retornar o a la que se retorna se debería reconstruir con lo que fue despojada.

Ocuparla de objetos y relatos que destaquen las estrategias de supervivencia y muestren otras perspectivas del exilio vinculadas, por ejemplo, al género o a la edad, me parece un acto de reparación e inclusión significativo. Como sabemos, las historias de exilio contienen violaciones a derechos fundamentales y están cargadas de impunidad, por eso se debe presentar la dignidad con la que este grupo de víctimas se enfrentó a la persecución y a los obstáculos de la violencia y la discriminación en el país y en el exterior.

Recuerdo que en los preparativos de la muestra quería, entre otras cosas, que la instalación llevara al espectador a la reflexión, no sólo de un pasado sino del estado presente de la situación del exilio. En una clase de Historia de la Violencia Moderna, le expliqué al profesor Alejandro Kaufman lo que quería hacer en la muestra y me recomendó la experiencia del artista alemán Horst Hoheisel. Él había hecho una convocatoria en Argentina para que la población llevara objetos que le recordaran a la última dictadura cívico-militar. La convocatoria tuvo acogida y con ese material se realizó la muestra "Química de la Memoria" en 
Buenos Aires y Rosario en el 2006 y 2007. El artista en esa muestra, como en otras, quiso deconstruir monumentos de cemento e intentar que sus obras activaran los sentidos del público, que la intervención artística los interrogara.

Creo, tal vez ingenuamente, que una muestra que pretenda transmitir memoria debe también dirigirse a generar inquietud por la verdad y la justicia. Quizá en ese camino se pueda alcanzar una parte, aunque sea pequeña de la reparación. Me parece que un ideal de una muestra de memoria en Colombia debería incluir elevar la versión de las víctimas, para así aportar a las garantías de no repetición. Por ejemplo, que una muestra de exilio conduzca a debatir las condiciones de participación política de los retornados es una apuesta para que nunca más se sientan en una "casa ajena". 


\section{REFERENCIAS BIBLIOGRÁFICAS}

Aceves Lozano, Jorge E. (1998). La historia oral y de vida: del recurso técnico a la experiencia de investigación. En Galindo Cáceres, Luis Jesús, Técnicas de investigación en sociedad, cultura y comunicación, Ed. Addision Wesley Longman. (Pp. 207-252).

Achiron, M. (2001). Un tratado imperecedero acosado. Revista Refugiados (111), pp. 6-11.

Acnur. (2014). Tendencias Globales: Mundo en Guerra. pp. 3-56. Recuperado de

ACNUR:

http://www.acnur.org/t3/fileadmin/scripts/doc.php?file=t3/fileadmin/Documentos/ Publicaciones/2015/10072

Acnur. (2015). Tendencias Globales: Desplazamiento Forzado en 2015. Forzados a Huir. Recuperado de ACNUR:

http://www.acnur.org/fileadmin/scripts/doc.php?file=fileadmin/Documentos/Publi caciones/2016/10627

Arrieta, Enán \& Baigorria, Ursula. (2016). Desplazamiento forzado externo y justicia transicional en Colombia. p. 27

Arsenault, Stéphanie. (2009). Transnacionalización de la subsistencia familiar: El caso de los refugiados colombianos en Quebec. Revista Migraciones Internacionales. Vol.5 no.1, Tijuana ene./jun.

Bolzman, Claudio. (2012). Elementos para una aproximación teórica al exilio. Revista Andaluza de Antropología ( $\left.{ }^{\circ} 3\right)$, pp. 7-30

Borón, Atilio. (2012). América Latina en la Geopolítica del Imperialismo. Buenos Aires. Ediciones Luxemburg.

Calloni, Stella. (2005). Operación Cóndor. La Habana. Editorial Ciencias Sociales. 
Canal Capital. (2015). Especial: Relatos del exilio. Capítulo inaugural. Disponible en: https://www.youtube.com/watch?v=Um7vRyj8Z_o

Canal Capital. (2015). Especial: Relatos del exilio, Bélgica. Capítulo Séptimo. https://www.youtube.com/watch?v=BChkhmh8JMI

Centro Nacional de Memoria Histórica. (2014). Cruzando la Frontera: Memorias del éxodo hacia Venezuela. El caso del río Arauca. Bogotá.

Centro Nacional de Memoria Histórica. (2015). Una nación desplazada: informe nacional del desplazamiento forzado en Colombia, Bogotá, CNMH - UARIV.

Centro Nacional de Memoria Histórica. (2014). No hubo tiempo para la tristeza. (CD). Bogotá.

CINEP. (2009). Panorama de Violencia Política y Violencia Política. Revista Noche y Niebla. (No. 39). Enero-junio. Bogotá.

Cipriani, Roberto. (2013). Sociología Cualitativa. Las Historias de vida como metodología científica. Buenos Aires. Editorial Biblos. P. 186

CODHES. (1999). Un país que huye. Desplazamiento y violencia en un País fragmentado. Bogotá: CODHES.

Comunicado Exiliados y perseguidos por el Estado Colombiano. (2016, febrero). http://www.aipazcomun.org/wp-content/uploads/2016/03/Intervencio\%CC\%81nen-el-PE-de-la-CxPaz-Exiliadas_os-perseguidos_x-EC.-BRUSELAS-23-feb20162.pdf Bruselas.

Conferencia Diplomática sobre la Reafirmación y el Desarrollo del Derecho Internacional Humanitario. (8 de junio de 1977). Protocolo II, adicional a los Convenios de Ginebra del 12 de agosto de 1949. Relativo a la protección de las Víctimas de los conflictos armados sin carácter internacional. Ginebra.

Conversatorio de ciudadanos por la paz. (2015, julio). Recuperado de: https://www.youtube.com/watch?v=COuWEFBHurU Paris.

El Mercurio; Connectas. (2014, noviembre). El Nuevo Éxodo Latino de Colombia a Chile. Recuperado de: http://www.connectas.org/exodo/index.html\#home 
Gómez, Andrei. (2007). Bloques perpetradores y mentalidad genocida: el caso de la unión patriótica en Colombia. Segundo Encuentro Internacional sobre Prácticas Sociales Genocidas. pp. 42-55

Gómez-Suárez, Andrei. (2013). La coyuntura geopolítica genocida de la destrucción de la Unión Patriótica (1985-2010). Estudios Políticos, 43, Instituto de Estudios Políticos, Universidad de Antioquia, (pp. 180-204).

Ginzburg, Carlo (2008). Mitos, emblemas e indicios: Morfología e historia. Barcelona, España. Editorial Gedisa.

Ginzburg, Carlo (2008). El queso y los gusanos. Barcelona, España. Ediciones Península. P. 218

Global Voice (2015, marzo). Los desafíos de la migración intra americana: La ruta Colombia-Chile. Recuperado de:

http://es.globalvoicesonline.org/2015/03/18/los-desafios-de-la-migracion-intraamericana-la-ruta-colombia-chile/

Hall, Stuart. 1996. Cuestiones de identidad cultural. Introducción, ¿quién necesita identidad? Buenos Aires. Amorrortu editores.

Hernández Sampieri, Roberto; Fernández Colledo, Carlos; Pilar Baptista, Lucio. (2006). Metodología de la Investigación. Cap. 15 Diseños del proceso de investigación cualitativa. Quinta Edición, Mc Grall Hill. PP. 490-520

Iranzo, Ángela. Los 'exiliados' de la Ley 1448: las víctimas en el exterior. Recuperado de: http://www.eltiempo.com/politica/justicia/analisis-cei-uniandeslos-colombianos-victimas-en-el-exterior/15152319

Jiménez, Blanca Inés. (2011). La Migración Internacional Forzada: Una Ruptura con los Proyectos de Vida. Revista Trabajo Social, No. 13, Ene.-Dic. Pp. 77-94. Colombia.

Kaufman, Alejandro. (2011). Historia y memoria: algunas indagaciones teóricas para el marco analítico latinoamericano. En Andreozzi Gabriele (coord.) Juicios por crímenes de lesa humanidad en Argentina. Buenos Aires. Cara o Ceca. 
Ley $N^{\circ}$ 387. Prevención del desplazamiento forzado. Diario Oficial de la República de Colombia. No. 43.091. Ibagué, Colombia, 18 de julio de 1997.

Ley N 975. Ley de Justicia y Paz. Diario Oficial de la República de Colombia No. 45.980. Bogotá, Colombia, 25 de julio de 2005.

Ley $N^{\circ}$ 1448. Ley de Víctimas y de Restitución de Tierras. Diario Oficial de la República de Colombia. Bogotá, Colombia, 10 de junio de 2011.

Lewis, Oscar. (1966). Los hijos de Sánchez. México. Editorial Joaquín Mortís.

Lewis, Oscar. (1961). Antropología de la Pobreza. México. Fondo de Cultura Económica.

Luzanni, Telma. (2012). Territorios Vigilados. Buenos Aires. Debate.

Manteca, Carlos. (2015). Eslabones. Buenos Aires. Ediciones Fabro.

Ministerio de Relaciones Exteriores. (2012). Guía Víctimas en el Exterior. Bogotá, Colombia.

Mut Montalvà, Elena. (2015). El activismo de las refugiadas políticas colombianas. Tesis de Postgrado. Recuperado de: http://roderic.uv.es/handle/10550/49830

Novick, S. (2012). La Política Migratoria Argentina a Contrapelo de la Tendencia Mundial. Voces en el Fénix (21), pp. 7-11. Argentina.

OIM. (2012). Perfil Migratorio de Argentina. Buenos Aires: Oficina Regional para América del Sur. Argentina.

Ortíz, Diana; Kaminke, Sergio. (2014). Suramérica y los refugiados colombianos. En revista interdisciplinaria movilidad humana. $\mathrm{N}^{\circ} 43$ p. 37-42

Ospina, William. (2001). Colombia en el Planeta. Gobernación de Antioquia, Secretaría de Educación y Cultura. Medellín.

Pecaut, Daniel. (5 de febrero, 2005). Un mayor compromiso con este país. Universidad del Valle. Colombia. 
Ramírez, Renzo. (2005). Sociedad, familia y género. El caso de los migrantes y exiliados colombianos en Suecia. Revista de Estudios Sociales, № 21, Bogotá. mayo /agosto.

Ramírez, Catalina. (2011). Refugiados Colombianos en Chile. Éxodo del Conflicto Armado. Tesis de pregrado. Recuperado de: http://bibliotecadigital.academia.cl/bitstream/handle/123456789/977/tsoc142.pdf .pdf?sequence $=1 \&$ isAllowed $=y$

Robledo, Catalina \& Serrano, Carolina. (1999). El DIH y su aplicabilidad en Colombia. Cap. 5, Aplicación del Protocolo II y sus Efectos en Colombia. (Tesis de pregrado). Universidad Pontificia Javeriana. Bogotá, Colombia. P. 50-76

Roniger, Luis. (2010). Exilio y democracia. En América Latina Hoy. Vol. 55. Agosto. Pp. 143-172. Salamanca, España.

Santana, Adalberto. (2015). Exilio y antiimperialismo latinoamericano. En Revista Cuadernos Americanos 152. pp. 39-49. México.

Vásquez, Albeiro. (2015). La Política Pública Migratoria y su Incidencia en las Trayectorias Migratorias De No Retorno, Retorno y Re-Emigración de la Población Colombiana 2007-2014. Tesis de Pregrado. Recuperado de: http://repository.javeriana.edu.co/bitstream/10554/15889/1/VasquezCasallasAlb eiro2015.pdf

Vega, Renán. (2015). Injerencia de los Estados Unidos, contrainsurgencia y terrorismo de Estado. Informe de contribución al entendimiento del conflicto de la Comisión Histórica. PP. 697-753. Colombia. 